
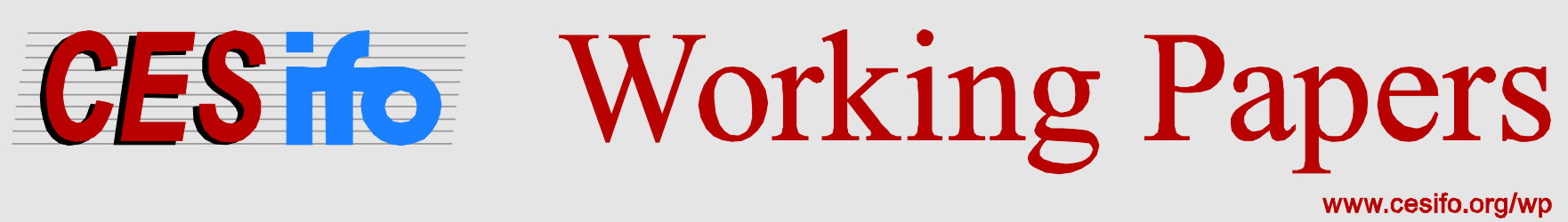

\title{
Finance and Income Inequality: A Review and New Evidence
}

\author{
Jakob de Haan \\ Jan-Egbert Sturm
}

CESIFO WORKING PAPER NO. 6079

CATEgORY 7: MONETARY POLICY AND INTERNATIONAL FINANCE

SEPTEMBER 2016

An electronic version of the paper may be downloaded

- from the SSRN website:

- from the RePEc website:

- from the CESifo website:

WwW.SSRN.com

Www.RePEc.org

www.CESifo-group.org/wp 


\title{
Finance and Income Inequality: A Review and New Evidence
}

\begin{abstract}
Using a panel fixed effects model for a sample of 121 countries covering 1975-2005, we examine how financial development, financial liberalization and banking crises are related to income inequality. In contrast with most previous work, our results suggest that all finance variables increase income inequality. The level of financial development conditions the impact of financial liberalization on inequality. Also the quality of political institutions conditions the impact of financial liberalization on income inequality, in contrast to the quality of economic institutions. Our main findings are robust for using random effects, cross-country regressions and legal origin as instrument for financial development.
\end{abstract}

JEL-Codes: D310, D630, F020, O110, O150.

Keywords: income inequality, financial liberalization, financial sector size, financial crises, political institutions.

Jakob de Haan

Department of Economics

University of Groningen

P.O.Box 800

The Netherlands - G700 Groningen AV

jakob.de.haan@rug.nl
Jan-Egbert Sturm

KOF Swiss Economic Institute

ETH Zurich

LEE G 116, Leonhardstrasse 21

Switzerland - 8092 Zurich

sturm@kof.ethz.ch

Version: September 2016 


\section{Introduction}

We examine the relationship between finance and income inequality using panel fixed effects regressions for a large sample of countries. To be more precise, we analyze how financial development, financial liberalization and financial crises are related to within country income inequality. As dependent variable we use five-year averages of Gini coefficients based on households' gross income from Solt's (2009) Standardized World Income Inequality Database (SWIID).

There is an extensive literature on the relationship between financial development and income inequality. ${ }^{1}$ Theoretically, the impact of financial development is ambiguous. On the one hand, more finance may make it easier for poor individuals to borrow for viable projects, which may reduce income inequality (Galor and Moav, 2004). Financial imperfections, such as information and transaction costs, may be especially binding on the poor who lack collateral and credit histories so that relaxation of these credit constraints may benefit the poor (Beck et al., 2007). On the other hand, improvements in the formal financial sector could be more likely to benefit the well-off who rely less on informal connections for capital (Greenwood and Jovanovic, 1990). As will be discussed in more detail in section 2, the empirical evidence on the relationship between financial development and income inequality is very mixed. Instead of providing yet another set of regressions that possibly adds to this diversity, we examine whether institutional quality conditions the relationship between financial development and income inequality, which may shed some light on the reasons why studies reach different conclusions. According to Rajan and Zingales (2003), in weak institutional environments established interests have privileged access to finance so that financial development induced by captured direct controls is likely to hurt the poor. In the presence of strong institutions, financial development may reduce inequality, allowing the poor to invest in human and physical capital (Law et al., 2014). A similar argument can be made for financial liberalization (Delis et al., 2014).2

\footnotetext{
${ }^{1}$ See Claessens and Perotti (2007) and Demirgüç-Kunt and Levine (2009) for excellent reviews of the literature.

2 Delis et al. (2014, p. 1824) argue that "quality institutions might enhance the impact of regulations on the distribution of income and weaker institutions may undermine such an impact." However, they do not examine this. The present study therefore is the first to examine whether the impact of financial liberalization on income inequality is conditioned by institutional quality.
} 
In recent decades there has been a global push to liberalize the financial sector. A small, but growing line of literature examines the impact of financial liberalization on income inequality. For instance, Beck et al. (2010) assess the impact of U.S. bank deregulation of the 1970s to the 1990s on the distribution of income and find that deregulation significantly reduces inequality by boosting incomes in the lower part of the income distribution but has little impact on incomes above the median. Likewise, some recent studies (Agnello et al., 2012; Delis et al., 2014; Li and Yu, 2014) based on crosscountry data report that financial liberalization reduces income inequality, but Jaumotte and Osuorio Buitron (2015) and Naceur and Zhang (2016) conclude that financial liberalization increases inequality (see section 2 for more details). Bumann and Lensink (2016) suggest that the impact of financial liberalization on inequality is conditioned by financial development. In their view, "financial liberalization will improve income distribution in countries where financial depth is high. The main reason for our finding is that in countries with high financial depth, the interest rate elasticity of loan demand is high. A financial liberalization policy that improves bank efficiency and reduces borrowing costs will lead to a sharp increase in aggregate loan demand, requiring an increase in the deposit rate to restore equilibrium in the financial market. The increase in the deposit rate improves the income of savers and, hence, income distribution" (p. 144). ${ }^{3}$ We will examine whether financial development conditions the impact of financial liberalization on income inequality.

A third financial variable that we consider are financial crises. Conventional wisdom is that the poor suffer disproportionately from recessions following financial crises. However, Denk and Cournede (2015) do not find a significant effect of banking crisis in their analysis of income inequality in OECD countries. Only few studies (e.g. Baldacci et al., 2002; Agnello and Sousa, 2012 and $\mathrm{Li}$ and $\mathrm{Yu}, 2015$ ) analyze the causal relationship between financial crises and income inequality for a broader set of countries and report mixed findings.

Our contribution to the literature is threefold. First, we include financial development, financial liberalization and financial crises in our empirical analysis of the relationship between finance and income inequality. Previous studies include at best two of

\footnotetext{
${ }^{3}$ In their model, agents with the best investment skills become investors, and earn the highest amount of money and agents with fewer investment skills become savers, and earn less money.
} 
these variables at the same time. Second, we use different indicators of financial liberalization. Like previous studies we use the financial liberalization data of Abiad et al. (2010), but also construct an alternative indicator based on some components of the economic freedom index of the Fraser Institute (Gwartney et al., 2015). This enables us to check how sensitive results are for the way financial liberalization is measured. Third, we examine whether the impact of finance on income inequality is conditioned by: (1) the level of financial development as suggested by Bumann and Lensink (2016); and (2) institutional quality as suggested by Rajan and Zingales (2003).

Our results suggest that a higher level of financial development, financial liberalization and the occurrence of a banking crisis all increase income inequality in a country. In contrast to the prediction by Bumann and Lensink (2016), our results suggest that with high levels of financial development, financial liberalization increases income inequality. We also find evidence that, unlike the quality of economic institutions, the quality of political institutions conditions the impact of financial liberalization on income inequality: with higher levels of democratic accountability the positive effect of financial liberalization on inequality increases. Institutional quality does not condition the impact of financial development on income inequality, in contrast to the prediction by Rajan and Zingales (2003).

The remainder of the paper is structured as follows. Section 2 discusses related studies in more detail. Section 3 describes our methodology and data used, while section 4 presents the main results. Section 5 offers a sensitivity analysis and section 6 concludes.

\section{Literature review}

As pointed out by Demirgüç-Kunt and Levine (2009), theory provides ambiguous predictions for the impact of finance on income distribution. A distinction can be made between the effects of finance on the extensive and the intensive margin. The extensive margin is about the use of financial services by individuals who had not been using those services. For example, financial development may help poor families to borrow to pay for education. Inequality falls in models with this mechanism (Galor and Moav, 2004). ${ }^{4}$ The

\footnotetext{
${ }^{4}$ However, the question is whether financial development as such reduces these financial frictions. Perhaps these frictions can be reduced by other factors, such as technology, without a larger financial sector (Demirgüç-Kunt and Levine, 2009). This suggests that other financial sector characteristics
} 
effect of financial development on income inequality on the intensive margin is different. Improvements in the quality and range of financial services do not tend to broaden access to financial services, but instead improve the quality of financial services enjoyed by those already purchasing financial services (Greenwood and Jovanovic, 1990). The benefits of these intensive margin effects accrue primarily to the rich, widening the distribution of income.

The extensive empirical literature on the relationship between financial development and income inequality provides very mixed findings. ${ }^{5}$ Although several studies report that countries with higher levels of financial development have less income inequality (see e.g. Li et al. 1998, Clarke et al., 2006, Beck et al., 2007, Kappel, 2010, Hamori and Hashiguchi, 2012 and Naceur and Zhang, 2016), ${ }^{6}$ other studies report a non-linear relationship (e.g. Kim and Lin, 2011 and Law et al., 2014), ${ }^{7}$ mixed results (Bahmani-Oskooee and Zhang, 2015), ${ }^{8}$ or a

than size should be examined. Most empirical research focuses, however, on financial sector size, a recent exception being the study by Naceur and Zhang (2016).

${ }^{5}$ Here we only discuss research using macro data for a large set of countries. For a discussion of other types of research we refer to Demirgüç-Kunt and Levine (2009).

${ }^{6} \mathrm{Li}$ et al. (1998) use data for 49 countries over the 1947-94 period and report a strong relationship between income inequality and their measure for financial development (M2/GDP). Beck et al. (2007) report a negative relationship between financial development (proxied by private credit-toGDP) and the growth rate of the Gini coefficient, which holds when controlling for real per capita GDP growth, lagged values of the Gini coefficient, and a wide array of other country-specific factors. Their sample consists of 65 countries over the period 1960-2005. Using a similar model for a larger group of countries (83) but a shorter sample period (1960-1995), Clarke et al. (2006) also find that financial development reduces inequality. Kappel (2010), who uses a sample of 59 countries for a cross-country analysis and 78 countries for a panel analysis over the period 1960 to 2006, concludes that financial development reduces income inequality for high-income countries, but is not significant for low-income countries. Hamori and Hashiguchi (2012) use annual panel data for a sample of 126 countries over the 1963-2002 period and find that both M2/GDP and private credit-toGDP reduce estimated household income inequality when they use panel fixed effects and GMM. Naceur and Zhang (2016) use a sample of 143 countries from 1961 to 2011 and find that several dimensions of financial development considered (access, efficiency, deepening and stability) can significantly reduce income inequality and poverty, while financial liberalization tends to exacerbate them.

${ }^{7}$ Based on a sample of 65 countries for 1960-2005, Kim and Lin (2011) find that the benefits of financial development on income distribution occur only when the country has reached a threshold level of financial development. Below this critical threshold, financial development exacerbates income inequality. Using data for 81 countries over the period 1985-2010 in a cross-section model, Law et al. (2014) conclude that financial development tends to reduce income inequality only after a certain threshold level of institutional quality has been achieved. Until then, the effect of financial development on income inequality is nonexistent.

8 Using time series regressions for 17 countries, Bahmani-Oskooee and Zhang (2015) report that only in three out of the 10 countries where finance has a short-term equalizing effect on income 
positive relationship between financial development and income equality. For instance, Jauch and Watzka (2012), who use a panel of 138 countries for the years 1960-2008, find that financial development increases income inequality when they use fixed effects and control for GDP per capita. Jaumotte et al. (2013) investigate income inequality with a focus on trade and financial globalization. In their sample of 51 countries from 1981 to 2003, they include private credit over GDP as a control variable and obtain a positive and significant coefficient for financial development. Similar results are reported by Dabla-Norris et al. (2015), who conclude that financial deepening is one of the main drivers of the increase in income inequality in their sample covering 97 countries and five-year panels over the period 1980-2012.

In the panel regressions for the Gini coefficient in a sample of 18 Asian countries over the 1996-2005 reported by Li and Yu (2015) the coefficient of credit-to-GDP is positive and significant. Likewise, Denk and Cournède (2015) conclude that more finance is associated with higher income inequality in their sample of 33 OECD countries. This relationship holds when intermediated credit and stock market capitalization are used to measure the size of finance. Financial sector employees are very strongly concentrated at the top of the income distribution, and their earnings exceed those of employees with similar profiles (such as age, gender or education) in other sectors (Denk, 2015).

Whereas most studies discussed do not explore the transmission from finance to inequality, Gimet and Lagoarde-Segot (2011) examine specific channels linking banks, capital markets and income inequality. They construct a set of annual indicators of banking and capital market size, robustness, efficiency and international integration and then estimate the determinants of income distribution using a panel structural vector autoregressive model for 49 countries over the 1994-2002 period. ${ }^{9}$ These authors conclude that financial sector development increases income inequality and that this impact seems to run primarily via the banking sector; Naceur and Zhang (2016) reach the same conclusion.

Finally, some studies suggest that the impact of financial development on income inequality may be conditioned by the quality of institutions (cf. Delis et al., 2014 and Law et

\footnotetext{
distribution the improvement lasts in the long run.

${ }^{9}$ In view of the quality and frequency of data on income inequality, we have serious doubts about using annual data on income inequality. This critique also applies to other studies using annual data such as Li and Yu (2014), Bahmani-Oskooee and Zhang (2015) and Naceur and Zhang (2016).
} 
al., 2014). For instance, under low quality of economic institutions financial development (or financial liberalization) may not affect inequality due to lack of judicial protection for the poor (Chong and Gradstein 2007). Likewise, Rajan and Zingales (2003) argue that under weak political institutions de jure political representation is dominated by de facto political influence allowing established interests to influence access to finance so that they benefit more from financial development than the poor.

Several arguments have been put forward in the literature suggesting that financial sector liberalization may affect income distribution. First, imperfections in the credit market prevent the poor from making productive investment, in for instance, education (Banerjee and Newman, 1991). If financial liberalization reduces these credit market imperfections, income inequality may be reduced. Second, financial reforms may lead to more equal access to credit thereby improving the efficiency of the domestic financial system (Abiad et al., 2008).

A few studies examine the relationship between financial sector liberalization and income inequality using cross-country data (most of these studies use the database of Abiad et al. (2010) for measuring liberalization; see section 3 for further details). Das and Mohapatra (2003) find that liberalization of equity markets benefits people in the top quintile of the income distribution at the expense of the 'middle class', while people in the lowest income shares are not affected. Using a panel of 62 countries for 1973-2005, Agnello et al. (2012) analyze the impact of financial reforms on income inequality. Their evidence suggests that removal of policies towards directed credit and excessively high reserve requirements, and improvements in the securities market reduce income inequality. Likewise, Delis et al. (2014) conclude that higher liberalization of banking generally leads to narrower income distribution. Yet, they also find that this effect is not uniform across all liberalization policies, nor is it the same across countries with different levels of development or different types of financial environments. In particular, the abolishment of credit controls decreases income inequality substantially, and this effect is long lasting. Li and $\mathrm{Yu}$ (2014) report for 18 countries in Asia for the 1996-2005 period that financial reform is effective in reducing income inequality, but that the effect is more profound in a country with higher human capital. Jaumotte and Osuorio Buitron (2015) investigate income inequality in 20 advanced economies during 1980-2010 with a focus on labor 
market institutions and include the index of Abiad et al. (2010) as control variable. They find that its coefficient is significantly positive. ${ }^{10}$ Also Naceur and Zhang (2016) report that financial liberalization increases inequality.

Christopoulos and McAdam (2015) examine the link between financial reforms and the stabilization of income inequality using panel unit root tests extended to allow for the presence of some covariates. Their results suggest that although both gross and net Gini indices follow a unit root process this picture changes when the various financial reforms indices are considered as additional covariates in the standard panel unit root approach. In particular whilst gross Gini coefficients are generally not stabilized by financial reforms, net measures are more likely to be stabilized.

Bumann and Lensink (2016) argue that the impact of financial liberalization on inequality is conditioned by financial development. Their theoretical model suggests that financial liberalization will improve income distribution in countries where financial depth is high. The authors' empirical results suggest that their measure of financial liberalization, i.e. capital account liberalization, only tends to lower income inequality if the level of financial depth, as measured by private credit over GDP, exceeds 25 percent. These results stand in contrast to the findings of Furceri and Loungani (2015). Based on panel data for 149 countries from 1970 to 2010, these authors conclude that, on average, capital account liberalization increases inequality. In addition, their results suggest that capital account liberalization leads to larger increases in inequality in countries with a weak level of financial institutions and when they are followed by episodes of financial crises.

Finally, we consider the impact of financial crises on income inequality. Wealth losses due to a financial crisis probably will hit the top of the income distribution. However, lowincome individuals will be hit more if the financial crisis is followed by an economic downturn (which is not always the case). Indeed, according to the OECD (2013), during the global financial crisis the average market income inequality across OECD countries increased by 1.4 percentage points. Looking at the 17 OECD countries for which data are available over a long time period, market income inequality increased by more between

\footnotetext{
${ }^{10}$ This finding is consistent with the results reported by Phillippon and Reshef (2013) who examine long-run trends in finance in a few advanced economies. They find that financial deregulation increased the demand for skills in the financial sector and that relative wages in the financial sector are related to skill-intensity.
} 
2007 and 2010 than what was observed in the previous 12 years. However, Denk and Cournede (2015) do not find a significant effect of banking crisis crises in their analysis of income inequality in 33 OECD countries during 1970-2011. As far as we know, only few studies have examined the causal relationship between financial crises and income inequality for a broader set of countries. Baldacci et al. (2002) report that currency crises have a positive impact on the Gini coefficient. In their analysis of income inequality in Asian countries, Li and Yu (2015) include a banking crisis dummy and find that it has a positive relationship with the Gini coefficient (crises lead to more inequality). Also Atkinson and Morelli (2011) find that income inequality is likely to increase after a banking crisis. In contrast, Agnello and Sousa (2012), who use annual data for 62 OECD and non-OECD countries for the 1980-2006 period find mixed results. While for OECD countries a banking crisis reduces inequality, for non-OECD the authors observe a significant rise in inequality before the onset of the crisis but no effect thereafter. In contrast, for a sample of developing countries, Honohan (2005) does not find evidence for a significant difference between Gini coefficients before and after a banking crisis. Likewise, Jaumotte and Osuorio Buitron (2015) do not report a significant impact of banking crises on income inequality.

While there is limited research on a causal relationship between financial crisis and inequality, the causality in the other direction, i.e. from (increases in) income inequality to financial crises, has received substantial attention. High or rising income inequality may cause low-income groups to leverage in order to increase or maintain consumption levels which, in turn, may increase the likelihood of a financial crisis. The relative income theory, habit formations and a "keeping up with the Joneses" phenomenon may explain such behavior (see Atkinson and Morelli, 2011 for a further discussion). For instance, in the model of Kumhof and Rancière (2011) rising income inequality and stagnant incomes in the lower deciles lead workers to borrow to maintain consumption growth. This increases leverage, and eventually a shock to the economy leads to a financial crisis. Indeed, there is much evidence that financial crises are often preceded by credit booms (Schularick and Taylor, 2012).

However, the empirical evidence in support of causality running from inequality to financial crises is weak at best. Cross-country data indicate that banking crises have not systematically been preceded by rising inequality (Atkinson and Morelli, 2011; Bordo and 
Meissner, 2012), although Gu and Huang (2014) report some supporting evidence.11

\section{Data and method}

\subsection{Income inequality}

Our left-hand side variable is the Gini coefficient based on households' income from Solt's (2009) Standardized World Income Inequality Database (SWIID). We use the index that represents household income before taxes, as this shows inequality exclusive of fiscal policy. ${ }^{12}$ As pointed out by Delis et al. (2014) and Solt (2015), the SWIID database is the most comprehensive database and allows comparison across countries, because it standardizes income. ${ }^{13}$ The Gini coefficient is derived from the Lorenz curve and ranges between 0 (perfect equality) and 100 (perfect inequality). We acknowledge that the Gini coefficient is less than perfect and that other measures, such as the share of income of the lowest quintile, may sometimes be more appropriate. Data availability, however, dictates our choice. We construct averages of the Gini coefficients across 5 years where the Gini coefficients are centered at the middle of the five-year period.

We use five-year non-overlapping averages for three reasons (see also Dabla-Norris et al., 2015). First, annual macroeconomic data are noisy, and this applies especially for data on income inequality (Delis et al., 2014). Second, the annual income inequality data in SWIID are imputed for years for which no information was available in the underlying databases (there are only infrequent measures of inequality for much of Africa, Latin America, and Asia). Third, some of the explanatory variables used are only available for five-

\footnotetext{
${ }^{11}$ Atkinson and Morelli (2011) examine the relationship between crises and income inequality using case studies of banking crises over a 100-year period (1911-2010) in 25 countries. They conclude that "banking crises were preceded by falling inequality as many times as by rising inequality" ( $p$. 47). They also report that there "is more evidence that financial crises are followed by rising inequality" (p. 49). Using data from 14 advanced countries between 1920 and 2000, Bordo and Meissner (2012) report that credit booms heighten the probability of a banking crisis, but there is no evidence that a rise in top income shares leads to credit booms. Gu and Huang (2014) challenge these results on econometric grounds. Using a similar dataset, they "establish strong evidence for rising inequality as a significant determinant of credit booms and therefore financial crises in Anglo-Saxon countries and other similar economies" (p. 513). However, for other countries their evidence is not supportive for a positive causal link from inequality to crises.
}

${ }^{12}$ Using Gini coefficients for net income, as some studies do (e.g. Agnello et al., 2012) would complicate identification of the effect of finance on income inequality.

${ }^{13}$ Still, it is not without problems; see Galbraith (2012; chapter 2) for an extensive discussion. 
year intervals. Fourth, we are not so much interested in short-term, i.e. business cycle, driven effects.

We have considered using the World Income Inequality Database (WIID) instead of SWIID as source for data on income inequality. SWIID is based on WIID, but is supplemented by other sources and has all of its observations multiply-imputed (Jenkins, 2015). ${ }^{14}$ WIID often provides more than one Gini coefficient for the same country/year. To deal with this problem, we proceed as follows. We first take averages of country/year pairs that have the same quality label (high, average, low, not known). This reduces the number of potential duplicates to at most 4 (high, average, low, not known) per country/year pair. Next, we take the average Gini coefficient that belongs to the highest quality group so that we have one observation per country/year, which can be an average of several observations of the highest quality available. As we are not interested in short-run dynamics, our analysis is based on 5-year averages. As SWIID provides observations for each year, these averages can be easily computed. In WIID there are many missing observations. We considered two alternative approaches to construct proxies for the Gini coefficient measured over 5-year intervals. First, we take the Gini coefficients in the middle of this 5-year period, if available (Gini (WIID)). The downside of this approach is that we are not averaging out of a couple of adjacent years. As an alternative, we take a 5-years average (Gini 5 years avg (WIID)); this results in a non available in case at least one of these years is not available, thereby reducing the sample substantially.

[Table 1 here]

Table 1 presents some summary statistics for the gross and net Gini coefficients drawn from SWIID and the Gini coefficients constructed on the basis of WIID. As the table shows, the number of observations available for the income inequality measures based on WIID is much lower than for those based on SWID. When using data from WIID we cannot distinguish between market and net Gini coefficients. As pointed out by Solt (2015, p. 685) this is problematic: "mixing gross- and disposable-income observations ... suggests a simple failure to consider what is the theoretically relevant variable..." However, such a distinction

\footnotetext{
${ }^{14}$ We thank Stephen Jenkins for providing this database.
} 
would reduce the sample even further. It appears that about a quarter of the observations in WIID follow some kind of gross income concept.

The correlations reported in Table 1 support this and suggest that most of the WIID data are indeed based on a net income concept: the correlation of the WIID variables with our (preferred) gross Gini coefficient from SWIID is relatively low (0.6 or 0.5), whereas it is much higher with the net Gini coefficients from SWIID (around 0.9).

As we are interested in the impact of finance on income inequality before income redistribution and do want to be able to work with a respectable and representative sample, we decided against using the WIID data.

\subsection{Explanatory variables}

We measure financial development by private credit divided by GDP. This measure excludes credit to the central bank, development banks, the public sector, credit to state-owned enterprises, and cross claims of one group of intermediaries on another. Thus, it captures the amount of credit channeled from savers, through financial intermediaries, to private firms. It has advantages over alternative measures of financial development, such as M2 over GDP, which does not measure a key function of financial intermediaries, which is the channeling of society's savings to private sector projects (Beck et al., 2007). In addition, the evidence of Gimet and Lagoarde-Segot (2011) and Naceur and Zhang (2016) suggests that the impact of finance on income inequality runs via the banking sector rather than capital market capitalization. ${ }^{15}$

Figure 1 shows two scatter plots of our measures for income inequality and financial development. The graph on the left-hand side shows the relationship using the raw data. This graph does not suggest that there is a relationship between the two variables. The graph on the right-hand side shows the relationship controlling for country-fixed effects. This graph suggests that more financial development increases income inequality.

[Figure 1 here]

\footnotetext{
15 Using the data as described in Čihák et al. (2012), we also investigate whether the results are sensitive to using stock market capitalization as percentage of GDP as measure of financial development. Although this is reducing the sample substantially, the qualitative results tend to go in the same direction.
} 
We use two measures for financial sector liberalization. First, following previous studies we employ the data of Abiad et al. (2010) that is based on several sub-indices mostly pertaining to banking regulatory practices measured on a scale from 0 to 3 (fully repressed to fully liberalized). The database covers 91 economies over the 1973-2005 period and consists of seven indices of financial sector liberalization. Our first measure of financial liberalization is the sum of six sub-indices. As the sub-index on banking supervision is not about financial sector liberalization we exclude it. Our sample for which we use this proxy for financial liberalization consists of 89 countries (listed in Table A1 of the Appendix) and runs from 1975 to 2005.

As an alternative, we employ data from the Fraser Institute on economic freedom that has a broader coverage of the financial sector (as pointed out by Delis et al. (2014), the index of Abiad et al. (2010) primarily reflects policies related to the banking sector) ${ }^{16}$ and is available for more countries and more recent years. The economic freedom index covers up to 157 countries with data relevant for this paper being available for approximately 70 countries as far back as $1975 .{ }^{17}$ We use the sum of four sub-indices from the economic freedom database, namely the sub-indices 3D, 4C, 4D and 5A. These indices range between 0 (not free) to 10 (totally free). The first index refers to freedom to own foreign currency bank accounts and measures the ease with which other currencies can be used via domestic and foreign bank accounts. The second index is based on the percentage difference between the official and the parallel (black) market exchange rate. Countries with a domestic currency that is fully convertible without restrictions receive a score of ten. When exchange rate controls are present and a black market exists, the ratings will decline toward zero as the black-market premium increases toward more than 50\%. In the latter case, a zero rating is given. The third index measures controls of the movement of capital. The fourth index measures the extent to which the banking industry is privately owned, the extent to which credit is supplied to the government sector and whether controls on interest rates interfere with the market in credit. Our sample for which we use this proxy for financial liberalization

\footnotetext{
${ }^{16}$ The sub-indices of the index of Abiad et al. (2010) refer to credit controls and reserve requirements, interest rate controls, banking-sector entry, capital-account transactions, privatizations of banks, liberalization of securities markets, and banking-sector supervision and capital regulation.

17 The data go back to 1970 but cover only 53 countries. Several studies have examined the relationship between the overall economic freedom index and income inequality, see, e.g. Bergh and Nilsson (2010) and Sturm and de Haan (2015).
} 
consists of 121 countries (listed in Table A1 of the Appendix) and runs from 1975 to 2005.

Figures 2 and 3 show the relationship between our measures for income inequality and financial liberalization, again with and without controlling for fixed effects. The graphs without fixed effects do not suggest that there is a relationship between income inequality and financial liberalization, while those with fixed effects suggest that financial liberalization leads to more inequality.

[Figures 2 and 3 here]

Our crisis data come from Laeven and Valencia (2013) who provide information on the timing of systemic banking crises. Chaudron and de Haan (2014) show that this database is more reliable than competing financial crises databases. Crises are identified based on several criteria. First, there should be signs of financial distress in the banking

system. Banking crises are also identified by "significant banking policy intervention measures" of which they identify six (such as a deposit freeze or nationalizations). At least three of these measures need to have been implemented for a crisis to be classified as systemic. This condition is supplemented with three other criteria, namely that the share of nonperforming loans exceed 20 percent, bank closures make up at least 20 percent of banking assets and fiscal restructuring costs exceed 5 percent of GDP. Our crisis variable is one when a banking crisis started in the five-year period before and is zero otherwise.

\subsection{Method}

As we are interested in the within country relationship between finance and income inequality, we use a dynamic panel model instead of OLS cross-section regressions in our main analysis. As pointed out by Beck et al. (2007), a dynamic panel model has several advantages compared to cross-country regressions as the latter do not fully control for unobserved country-specific effects and do not exploit the time-series dimension of the data. The model estimated is:

$$
\text { Ineq }_{i, t}=\alpha_{i}+\alpha_{1} F D_{i, t-1}+\alpha_{2} F L_{i, t-1}+\alpha_{3} B C_{i, t-1}+\alpha_{4} \text { interactions }+\alpha_{5} X_{i, t}+u_{i, t}
$$

Where Ineq is income inequality, $F D$ is financial development, $F L$ is financial liberalization, $B C$ denotes the occurrence of a banking crisis and $X$ is a vector of control variables, while $u$ denotes the error term. Time lags are used to avoid endogeneity issues (but this may not be 
sufficient and therefore we consider alternative approaches below). For $F D$ and $F L$ we take values at the end of the five-year period preceding the period covered by the Gini coefficient (which is a five-year average), while the banking crisis dummy is one when a banking crisis started in any of the five years preceding the five-year period used for calculating the Gini coefficient. We have used a very long list of control variables based on previous studies (shown in Table A2 in the Appendix; Tables A3 and A4 provides summary statistics and a correlation matrix $)^{18}$

As pointed out in the Introduction, we focus on two interactions that, according to insights from the literature, may condition the impact of finance on income inequality. First, we examine whether the impact of financial liberalization on income inequality depends on the level of financial sector development. Second, we examine whether the impact of financial liberalization and/or financial development on income inequality is conditioned by institutional quality.

We have constructed two institutional quality variables using the ICRG database measuring the quality of political institutions and the quality of economic institutions, respectively. On a scale from zero (low quality) to six (high quality), the variable democratic accountability measures not just whether there are free and fair elections, but also how responsive government is to its people. This variable comes directly from the ICRG database. It measures precisely what e.g. Acemoglu and Robinson (2013, p. 36) have in mind when they explain why the quality of political institutions matters in explaining the different economic fates of Mexico and the US and the role of access to finance therein: "Unlike in Mexico, in the United States the citizens could keep politicians in check and get rid of ones who would use their offices to enrich themselves or create monopolies for their cronies. ... The broad distribution of political rights in the United States, especially when compared to Mexico, guaranteed equal access to finance and loans." Our indicator of the quality of economic institutions is the sum of three ICRG variables, namely bureaucratic quality, corruption and law and order (taking differences in scaling of these indicators into account) where a higher number indicates better quality.

\footnotetext{
18 Due to data availability some variables that have been suggested to be related to income inequality, such as technology (see e.g. Dabla-Norris et al., 2015), could not be included.
} 


\section{Main results}

Tables 2 and 3 present the results where we proceed as follows. First, we show the results when we do not include control variables. As our three finance measures may be related (e.g. more financial development may lead to more banking crises and a low level of financial development may be an incentive for countries to introduce financial liberalization), we first show simple bivariate regressions before including all our finance measures. In the next step we add the interactions outlined above. To interpret the interaction effects, we use graphs as suggested by Brambor et al. (2006). ${ }^{19}$ Finally, we add control variables in Table 2 that turn out to be significant (in Table 3 we include the same controls). In Table 2 the measure for financial liberalization based on Abiad et al. (2008) is used, while in Table 3 financial liberalization is proxied by the index based on several components of the Fraser Institute's economic freedom index, which captures more dimensions of the financial system than the index of Abiad et al. (2010).

[Tables 2 and 3 here]

In the first three columns of Tables 2 and 3 the financial sector variables are included separately, while column (4) shows the results when all finance measures are included. In the regressions in these columns we do not include interaction terms and control variables. The results suggest that financial development, financial liberalization and banking crises increase income inequality, also when they are included simultaneously.

Next we turn to the interaction of financial liberalization and financial development to examine whether financial development conditions the impact of financial liberalization on income inequality, as suggested by Bumann and Lensink (2016). The line in Figure 4 shows the marginal impact of financial liberalization on income inequality for different levels of financial development. The whiskers show the confidence band and the grey bars show the distribution of the observations. The graphs are based on the estimates reported in column (5) of both tables. The graphs in Figure 4 suggest that the impact of financial liberalization is conditioned by the level of financial development: the positive impact of

${ }^{19}$ Most studies discussed in section 2 that consider interactions draw conclusions on the basis of the significance of the interaction term, which generally is not the proper way to deal with interactions as shown by Brambor et al. (2006). 
financial liberalization on the Gini coefficient is higher when financial development is higher. This conclusion holds for both measures of financial liberalization. ${ }^{20}$ Adding time fixed effects does not change our conclusion (not shown; results available on request). So these results do not support the prediction of Bumann and Lensink (2015) that financial liberalization will decrease income inequality at high levels of financial development.

[Figure 4 here]

In the next step we consider institutional quality. We first add our proxies for the quality of political and economic institutions to the model shown in column (4). Including these variables may shed some light on the relevance of a potential criticism of our results, namely that inequality and financial development are both driven by institutional factors. For instance, according to Claessens and Perotti (2007, p. 749), "economic inequality and (financial) underdevelopment are jointly determined by institutional factors which cause unequal access to political and contractual rights." If true, adding proxies for institutional quality should affect our results. It turns out that democratic accountability is significant in contrast to our proxy for the quality of economic institutions which is therefore not shown in column (6) of Tables 2 and 3. Our results suggest that better political institutions reduce income inequality. Importantly, adding the quality of institutions does not change our previous finding that finance increases income inequality.

Figure 5 shows the marginal effects of financial liberalization on income inequality for different levels of democratic accountability. The graphs are based on the regressions shown in column (7) of Tables 2 and 3. They suggest that the positive impact of financial liberalization on the Gini coefficient is higher in countries with a higher quality of political institutions. In fact, at low levels of democratic accountability financial liberalization does not significantly affect income inequality. In these regressions we do not include the

\footnotetext{
${ }^{20}$ We have also examined the interaction of financial development and the Chin-Ito index for financial openness. Kunieda et al. (2014) argue that the relationship between financial development and income inequality is conditioned by financial openness. Their evidence, based on a sample of more than 100 countries for the period 1985-2009, suggests that in financially open countries (where financial openness is computed from the data set of Lane and Milesi-Ferretti, 2007), financial development (measured as private credit to GDP) increases income inequality, while in financially closed economies financial development decreases income inequality. Our results (available on request) do not provide evidence for this view.
} 
interaction between financial liberalization and financial development as financial development has been shown to be dependent on institutional quality (see e.g. Law and Azman-Saini, 2012).

Figure 6 presents the marginal effects of financial development on income inequality for different levels of democratic accountability. The graphs are based on the regressions shown in column (8) of Tables 2 and 3. They do not provide strong evidence that the impact of financial development on income inequality is conditioned by the quality of political institutions, in contrast to the prediction of Rajan and Zingales (2003) that under high-quality institutions financial development will reduce inequality.

The interactions of our finance variables and our proxy for the quality of economic institutions do not suggest that the impact of finance on income inequality is conditioned by the quality of economic institutions. For instance, Figure A1 in the Appendix shows the marginal effects of financial liberalization on the Gini coefficient for different levels of the quality of economic institutions. Although mostly significantly positive, the marginal effects of financial liberalization on inequality for different levels of institutional quality are not significantly different for different values of institutional quality (the whiskers overlap).

[Figures 5 and 6 here]

The next column in both tables shows the results when we add economic globalization to the model shown in column (7) of Tables 2 and 3. As said, we consider a long list of potential controls, but most of them are not significant. In line with findings of Sturm and de Haan (2015), globalization turns out to be significant in Tables 2 and 3 (column 9). Adding controls does not change our conclusions as shown by the marginal plot graphs (available on request).

\section{Sensitivity analysis}

In this section we present the outcomes of several sensitivity tests that have two purposes. First, as our results deviate from those of several previous studies, we examine to what extent our findings change when different empirical set-ups are used. Second, we further analyze whether our results are robust for endogeneity, which is a key issue in this type of 
analysis.

\subsection{Random effects models}

So far, our results are based on panel fixed effects models. In this section we present the outcomes of random effects models following Clarke et al. (2006) who use random effects arguing that using fixed effects takes away much (cross-country) variation. Since the Hausman tests often do not clearly indicate that fixed effects need to be used, it makes sense to also estimate random effects models. This has an additional advantage, namely that we can follow several previous papers (Clarke et al., 2006; Kappel, 2010; Kanieda et al. 2014 and Law et al., 2014) and use legal origin dummies as instruments for financial development. According to La Porta et al. $(1997,1998)$, the introduction of common or civil law into a country via conquest or colonization not only affected the legal rules but also institutions. For instance, the protection of property rights in common law countries, which impacts the development of financial markets, is stronger than that in civil law countries, notably in countries with French civil law. Therefore, legal origin dummies are frequently used as instrumental variables (cf. Acemoglu and Johnson, 2005).

Table 4 shows the outcomes. Columns (1)-(4) present the results when we use the measure for financial liberalization based on the data of Abiad et al., while columns (5)-(8) contain the results for the financial liberalization measure based on components of the economic freedom index.

Columns (1) and (5) show the results when we estimate the model shown in column (5) of Tables 2 and 3 which includes our finance variables and the interaction between financial liberalization and financial development allowing for random effects. It turns out that the results are very similar. Next, in columns (3) and (7) we include democratic accountability in the model containing our three finance measures together with its interaction with financial liberalization (cf. column (7) in Tables 2 and 3). Like before, the results suggest that finance increases inequality, while institutional quality decreases inequality. In countries where democratic accountability is high, the effect of financial liberalization turns significantly positive. Hence, moving to a random effects framework does not lead to different results.

Finally, columns (2), (4), (6) and (8) show the IV results. In columns (2) and (4) our measures for financial development and financial liberalization are taken up and allowed to 
interact. (This corresponds to the specification in column (5) of Tables 2 and 3). In columns (4) and (8) the interaction between the quality of political institutions and financial liberalization is included. (This corresponds to the specification in column (7) of Tables 2 and 3). The outcomes suggest that instrumenting financial development by legal origin does not lead to different outcomes (see also Figure A2 in the Appendix).

[Table 4 here]

\subsection{Cross-country regressions}

Next, we present cross-country regressions results in Table 5. Even though we feel that panel models are most appropriate for our purpose, we want to check whether our results are different when we focus on cross-country differences in income inequality rather than within-country income inequality. We only show the outcomes for the financial liberalization measure based on the data of Abiad et al., as this is the variable used in previous studies. We use the specification with the three finance variables, democratic accountability and the interaction between financial liberalization and democratic accountability for different cross-sections (1991-95, 1991-2000, 1991-2005, 1996-2000, 1996-2005, and 1996-2010). This corresponds to column (7) in Tables 2 and 3. The final three columns show the outcomes in case we again instrument financial development by legal origin using the latter time periods. The results for banking crises and financial liberalization are broadly in line with our findings based on panel estimates, but we now find some evidence that financial development reduces income inequality (although the estimated coefficient is not significant in most regressions). This suggests that our focus on within-country income inequality explains to some extent the difference between the results of our study for the impact of financial development on income inequality and those of previous studies focusing on cross-country income inequality. Another difference between the panel and the cross-country regressions is that the coefficient of the quality of political institutions is never significant in the latter.

[Table 5 here] 


\subsection{OECD countries}

In this section we report the results when we estimate some models for OECD countries only. Table 6 shows fixed effects panel regressions for the specifications shown in columns (4), (5) and (7) of Tables 2 and 3. Our prior is that the interactions will not be significant, as the countries in this subsample are much more homogeneous when it comes to financial development and institutional quality than is the case in our full sample. This indeed turns out to be the case. Still, our main result that finance increases income inequality is also confirmed for OECD countries, also when we use our alternative measure for financial liberalization (last three columns of Table 6).

[Table 6 here]

\section{Conclusion}

Our results suggest that financial development, financial liberalization and banking crises increase income inequality. In addition, the impact of financial liberalization on inequality seems to be conditioned by the level of financial development and the quality of political institutions. Our findings are in contrast to several previous studies that examined the relationship between financial development and income inequality.

As explained in section 2, theory is not clear whether financial development will increase or decrease income inequality. Our results suggest that financial development increases inequality, which is in line with the model of Greenwood and Jovanovic (1990). It is important, however, to stress that our results do not imply that financial development and financial liberalization are necessarily bad for the poor. There is a large literature showing that finance plays a positive role in promoting economic development (at least up to a point), ${ }^{21}$ which will benefit the poor. An interesting avenue for future research is to

\footnotetext{
21 Some recent studies suggest that this relationship may be non-linear. For instance, Arcand et al. (2012) report that at intermediate levels of financial depth, there is a positive relationship between the size of the financial system and economic growth, but at high levels of financial depth, more finance is associated with less growth. In fact, the marginal effect of financial depth on output growth becomes negative when credit to the private sector reaches 80-100 per cent of GDP. Likewise, Cecchetti and Kharroubi (2012) report that financial development has a non-linear impact on aggregate productivity growth. Based on a sample of developed and emerging economies, they show that the level of financial development is good only up to a point, after which it becomes a drag on
} 
model the effects of financial development and financial liberalization on income inequality and economic growth simultaneously.

Our finding that financial development on income inequality is not conditioned by democratic accountability is in contrast to the prediction of Rajan and Zingales (2003) that under high-quality institutions financial development will reduce inequality. However, we find evidence that the impact of financial liberalization is conditioned by the quality of political institutions. Our findings do also not support the theoretical prediction of Bumann and Lensink (2016) that financial liberalization will improve income distribution in countries where financial depth is high. To the contrary, our results suggest that financial development enhances the income inequality increasing effect of financial liberalization. To explain this finding is beyond the scope of the current paper and is left for future research. ${ }^{22}$

Finally, we like to stress that our results are based on Gini coefficients for gross income, thereby ignoring (on purpose) government redistribution policies. An interesting issue for future research is to examine whether countries that have higher income inequality due to finance, have decided to redress this inequality by more income redistribution. Likewise, it would be interesting to examine whether our results hold for other measures for income inequality. This requires, however, that such data become available for a larger set of countries than is currently the case.

\section{Acknowledgements}

The views expressed are those of the authors and do not necessarily reflect those of DNB. We like to thank participants in the DNB Annual Research Conference (November 20, 2015), research seminars at Deakin University (January 20, 2016), the National Bank of Serbia (February 26, 2016), IdEP, Lugano (April 12, 2016), and ISEG, Lisbon (June 23, 2016), as well as the European Public Choice conference (March, 30-April 2, 2016), the SUERF conference "Central banking and monetary policy: Which will be the new normal?"

growth.

${ }^{22}$ But their model can be easily be adjusted and made in line with our results by allowing highincome agents to have a higher saving rate. That would make them benefit more from the increased loan demand - that is more pronounced in financially developed countries - that is caused by financial liberalization than those with lower income levels. 
in Milan (April 14, 2016), the CESifo Venice Summer Institute (July 20, 2016), especially our discussant Stephanie Armbruster, the Silvaplana Workshop on Political Economy (July 31, 2016) and the VfS-Annual Conference (September 5, 2016) for their comments on previous versions of this paper.

\section{References}

Abiad, A., Detragiache, E., Tressel, T., 2010. A new database of financial reforms. IMF Staff Papers 57, 281-302.

Abiad, A., Mody, A., 2005. Financial reform: what shakes it? What shapes it? American Economic Review 95, 66-88.

Abiad, A., Oomes, N., Ueda, K., 2008. The quality effect: does financial liberalization improve the allocation of capital? Journal of Development Economics 87, 270-282.

Acemoglu, D., Johnson, S., 2005. Unbundling institutions. Journal of Political Economy 113, 949-995.

Acemoglu, D., Robinson, J.A., 2013. Why nations fail. The origins of power, prosperity and poverty. Penguin Random House, New York.

Agnello, L., Mallick, S.K., Sousa, R.M., 2012. Financial reforms and income inequality. Economics Letters 116, 583-587.

Agnello, L., Sousa, R.M., 2012. How do banking crises impact on income inequality? Applied Economics Letters 19, 1425-1429.

Arcand, J-L., Berkes, E., Panizza, U., 2012. Too much finance? IMF Working Paper 12/161.

Atkinson, A.B., Morelli, S., 2011. Economic crises and inequality. UNDP-HDRO Occasional Papers 2011/6.

Bahmani-Oskooee, M., Zhang, R., 2015. On the impact of financial development on income distribution: time-series evidence. Applied Economics 47, 1248-1271.

Baldacci, E., de Mello, L., Inchauste, G., 2002. Financial crises, poverty and income distribution. IMF Working Paper 02/4, International Monetary Fund, Washington.

Banerjee, A.V., Newman, A.F., 1993. Occupational choice and the process of development. Journal of Political Economy 101, 274-298.

Beck, T., Demirgüç-Kunt, A., Levine, R., 2007. Finance, inequality and the poor. Journal of Economic Growth 12, 27-49.

Beck, T., Levine, R., Levkov, A., 2010. Big bad banks? The winners and losers from bank deregulation in the United States. Journal of Finance 65, 1637-1667.

Bergh, A., Nilsson, T., 2010. Do liberalization and globalization increase income inequality? European Journal of Political Economy 26, 488-505.

Bordo, M.D., Meissner, C.M., 2012. Does inequality lead to a financial crisis? Journal of International Money and Finance 31, 2147-2161.

Brambor, T., Clark, W., Golder, M., 2006. Understanding interaction models: improving 
empirical analysis. Political Analysis 14, 63-82.

Bumann, S., Lensink, R., 2016. Capital account liberalization and income inequality. Journal of International Money and Finance 61, 143-162.

Cecchetti, S., Kharroubi, E., 2012. Reassessing the impact of finance on growth. BIS Working Paper 381.

Chaudron, R., de Haan, J., 2014. Dating banking crises using incidence and size of bank failures: four crises reconsidered. Journal of Financial Stability 15, 63-75.

Christopoulos, D., McAdam, P., 2015. Do financial reforms help stabilize inequality? ECB Working Paper 1780, European Central Bank, Frankfurt.

Chong, A., Gradstein, M., 2007. Inequality and institutions. The Review of Economics and Statistics 89, 454-465.

Čihák, M., Demirgüç-Kunt, A., Feyen, E., Levine, R., 2012. Benchmarking financial systems around the world. World Bank Policy Research Working Paper 6175, World Bank, Washington DC.

Claessens, S., Perotti, E., 2007. Finance and inequality: channels and evidence. Journal of Comparative Economics 35, 748-773.

Clarke, G., Xu, L. C., Zou, H., 2006. Finance and income inequality: what do the data tell us? Southern Economic Journal 72, 578-596.

Dabla-Norris, E., Kochhar, K., Ricka, F., Suphaphiphat, N., Tsounta, E., 2015. Causes and consequences of income inequality: a global perspective. IMF Staff Discussion Note 15/13, IMF, Washington DC.

Das, M., Mohapatra, S., 2003. Income inequality: the aftermath of stock market liberalization in emerging markets. Journal of Empirical Finance 10, 217-48.

Delis, M. D., Hasan, I., Kazakis, P., 2014. Bank regulations and income inequality: empirical evidence. Review of Finance 18, 1811-1846.

Demirgüç-Kunt, A., Levine, R., 2009. Finance and inequality: theory and evidence. Annual Review of Financial Economics 1, 287-318.

Denk, 0., 2015. Financial sector pay and labour income inequality: evidence from Europe. OECD Economics Department Working Paper 1225, OECD Publishing, Paris.

Denk, O., Cournède, B., 2015. Finance and income inequality in OECD countries. OECD Economics Department Working Paper 1224, OECD Publishing, Paris.

Galbraith, J.K., 2012. Inequality and instability. Oxford University Press, Oxford.

Galor, O., Moav, O. (2004). From physical to human capital accumulation: inequality and the process of development. Review of Economic Studies 71, 1001-1026.

Gimet, C., Lagoarde-Segot, T., 2011. A closer look at financial development and income distribution. Journal of Banking \& Finance 35, 1698-1713.

Greenwood, J., Jovanovic, B., 1990. Financial development, growth, and the distribution of income. Journal of Political Economy 98, 1076-1107.

$\mathrm{Gu}, \mathrm{X} ., \mathrm{Huang}, \mathrm{B} ., 2014$. Does inequality lead to a financial crisis? Revisited. Review of Development Economics 18, 502-516. 
Gwartney, J., Lawson, R, Hall, J., 2015. Economic freedom of the world. Available at: www.freetheworld.com.

Hamori, S., Hashiguchi, Y., 2012. The effect of financial deepening on inequality: some international evidence. Journal of Asian Economics 23, 353-359.

Honohan, P., 2005. Banking sector crises and inequality. World Bank Policy Research Working Paper 3659, World Bank, Washington DC.?

Jauch, S., Watzka, S., 2012. Financial development and income inequality: a panel data approach. CESifo Working Papers 3687, CESifo, Munich.

Jaumotte, F., Lall, S., Papageorgiou, C., 2013. Rising income inequality: technology, or trade and financial globalization? IMF Economic Review 61, 271-309.

Jaumotte, F., Osorio Buitron, C., 2015. Inequality and labor market institutions. IMF Staff Discussion Note 15/14, IMF, Washington DC.

Jenkins, S.J., 2015. World income inequality databases: an assessment of WIID and SWIID. Journal of Economic Inequality 13, 629-671.

Kappel, V., 2010. The effects of financial development on income inequality and poverty. CER-ETH Working Paper 10/127, ETH, Zürich.

Kim, D., Lin, S., 2011. Nonlinearity in the financial development-income inequality nexus. Journal of Comparative Economics 39, 310-325.

Kumhof, M., Rancière, R., 2011. Inequality, leverage and crises. IMF Working Paper 10/268, IMF, Washington DC.?

Kumhof, M., Rancière, R., Winant, P., 2015. Inequality, leverage and crises. American Economic Review 105, 1217-1245.

Kunieda, T., Okada, K., Shibata, A., 2014. Finance and inequality: how does globalization change their relationship? Macroeconomic Dynamics 18, 1091-1128.

Laeven, L., Valencia, F., 2013. Systemic banking crises database. IMF Economic Review 61, 225-270.

Lane, P.R., Milesi-Ferretti, G.M., 2007. The external wealth of nations mark II: revised and extended estimates of foreign assets and liabilities, 1970-2004. Journal of International Economics 73, 223-250.

La Porta, R., Lopez-de-Silanes, F., Shleifer, A., Vishny, R.W., 1997. Legal determinants of external finance. Journal of Finance 52, 1131-1150.

La Porta, R., Lopez-de-Silanes, F., Shleifer, A., Vishny, R.W., 1998. Law and finance. Journal of Political Economy 106, 1113-1155.

Law, S.H., Azman-Saini, W.N.W., 2012. Institutional quality, governance, and financial development. Economics of Governance 13, 217-236.

Law, S.H., Tan, H.B., Azman-Saini, W.N.W., 2014. Financial development and income inequality at different levels of institutional quality.? ?Emerging Markets Finance \& Trade 50, 21-33.

Li, H., Squire, L., Zou, H., 1998. Explaining international and intertemporal variations in income distribution. The Economic Journal 108, 26-43.

Li, J., Yu, H., 2014. Income inequality and financial reform in Asia: the role of human capital. 
Applied Economics 46, 2920-2935.

Furceri, D., Loungani, P., 2015. Capital account liberalization and inequality. IMF Working Paper 15/243

Naceur, S.B., Zhang, R., 2016. Financial development, inequality and poverty: some international evidence. IMF Working Paper 16/32, IMF, Washington DC.

OECD, 2013. Crisis squeezes income and puts pressure on inequality and poverty. OECD Publishing, Paris.

Philippon, T., Reshef, A., 2013. An international look at the growth of modern finance. The Journal of Economic Perspectives 27, 73-96.

Rajan, R.G., Zingales, L., 2003. The great reversals: the politics of financial development in the twentieth century. Journal of Financial Economics 69, 5-50.

Schularick, M., Taylor, A.M., 2012. Credit booms gone bust. Monetary policy, leverage cycles and financial crises, 1870-2008. American Economic Review 102, 1029-1061.

Solt, F., 2009. Standardizing the World Income Inequality Database. Social Science Quarterly $90,231-242$.

Solt, F., 2015. On the assessment and use of cross-national income inequality datasets. Journal of Economic Inequality 13, 683-691.

Sturm, J-E., de Haan, J., 2015. Income inequality, capitalism and ethno-linguistic fractionalization. American Economic Review (Papers and Proceedings) 105, 593597.

\section{Tables}

Table 1. Summary statistics of different Gini coefficients - SWIID vs. WIID

\begin{tabular}{|c|c|c|c|c|c|c|c|c|c|}
\hline \multirow[b]{2}{*}{ Variable } & \multirow[b]{2}{*}{ Obs } & \multirow[b]{2}{*}{ Mean } & \multirow[b]{2}{*}{ St. Dev. } & \multirow[b]{2}{*}{ Min } & \multirow[b]{2}{*}{ Max } & \multicolumn{4}{|c|}{ Correlation with } \\
\hline & & & & & & 1 & 2 & 3 & 4 \\
\hline 1 Gross Gini (SWIID) & 530 & 45.37 & 7.26 & 22.66 & 69.85 & 1 & & & \\
\hline 2 Net Gini (SWIID) & 530 & 38.20 & 9.45 & 19.43 & 66.20 & 0.70 & 1 & & \\
\hline 3 Gini (WIID) & 335 & 39.26 & 9.72 & 20.10 & 74.30 & 0.63 & 0.89 & 1 & \\
\hline 4 Gini 5 years avg. (WIID) & 184 & 36.98 & 8.92 & 21.32 & 58.40 & 0.52 & 0.90 & 0.97 & 1 \\
\hline
\end{tabular}


Table 2. Finance and income inequality: panel estimates (dependent variable: Gini coefficient; Abiad et al. data for financial liberalization)

\begin{tabular}{|c|c|c|c|c|c|c|c|c|c|}
\hline VARIABLES & (1) & (2) & (3) & (4) & $\begin{array}{c}\text { (5) } \\
\text { +interaction } \\
\end{array}$ & $\begin{array}{c}\text { (6) } \\
+ \text { democ }\end{array}$ & $\begin{array}{c}\text { (7) } \\
+ \text { democ }\end{array}$ & $\begin{array}{c}(8) \\
+ \text { democ }\end{array}$ & $\begin{array}{c}\text { (9) } \\
+ \text { +ec.glob-flows }\end{array}$ \\
\hline Start of a Systemic Banking Crisis during t -7 and $t-3$ & $\begin{array}{l}0.876^{* *} \\
(2.022)\end{array}$ & & & $\begin{array}{l}1.049^{* *} \\
(2.439)\end{array}$ & $\begin{array}{l}0.976^{* *} \\
(2.387)\end{array}$ & $\begin{array}{c}1.026^{* * *} \\
(2.800)\end{array}$ & $\begin{array}{c}0.940^{* * *} \\
(2.661)\end{array}$ & $\begin{array}{c}0.903^{* * * *} \\
(2.725)\end{array}$ & $\begin{array}{l}0.895^{* *} \\
(2.515)\end{array}$ \\
\hline Domestic credit to private sector (\% of GDP) & & $\begin{array}{c}0.0652^{* * *} \\
(5.089)\end{array}$ & & $\begin{array}{c}0.0518^{* * *} \\
(4.278)\end{array}$ & $\begin{array}{l}-0.0168 \\
(-0.507)\end{array}$ & $\begin{array}{c}0.0349^{* * *} \\
(3.405)\end{array}$ & $\begin{array}{c}0.0297^{* * *} \\
(3.002)\end{array}$ & $\begin{array}{l}0.0464 \\
(1.065)\end{array}$ & $\begin{array}{c}0.0247^{* * *} \\
(2.695)\end{array}$ \\
\hline Financial lib.: Abiad et al. index (corrected) & & & $\begin{array}{c}0.256 * * * \\
(4.153)\end{array}$ & $\begin{array}{c}0.155^{* * *} \\
(3.120)\end{array}$ & $\begin{array}{l}0.0186 \\
(0.245)\end{array}$ & $\begin{array}{c}0.202^{* * *} \\
(3.771)\end{array}$ & $\begin{array}{l}-0.146 \\
(-1.197)\end{array}$ & $\begin{array}{c}-0.178 \\
(-1.230)\end{array}$ & $\begin{array}{l}-0.198 \\
(-1.643)\end{array}$ \\
\hline c.domcredgdp\#c.finreform_cor & & & & & $\begin{array}{c}0.00404^{* *} \\
(2.325)\end{array}$ & & & & \\
\hline ICRG: Democratic Accountability & & & & & & $\begin{array}{l}-0.638^{* *} \\
(-2.430)\end{array}$ & $\begin{array}{c}-1.641^{* * *} \\
(-3.452)\end{array}$ & $\begin{array}{c}-1.557^{* * *} \\
(-3.677)\end{array}$ & $\begin{array}{c}-1.605^{* * *} \\
(-3.619)\end{array}$ \\
\hline c.democ\#c.finreform_cor & & & & & & & $\begin{array}{c}0.0895^{* * * *} \\
(2.920)\end{array}$ & $\begin{array}{c}0.0957^{* * *} \\
(2.653)\end{array}$ & $\begin{array}{c}0.0857^{* * *} \\
(2.863)\end{array}$ \\
\hline c.domcredgdp\#c.democ & & & & & & & & $\begin{array}{l}-0.00325 \\
(-0.429)\end{array}$ & \\
\hline Economic Globalization: Actual Flows & & & & & & & & & $\begin{array}{c}0.0628^{* * *} \\
(2.644)\end{array}$ \\
\hline Observations & 426 & 426 & 426 & 426 & 426 & 345 & 345 & 345 & 338 \\
\hline R-squared & 0.011 & 0.173 & 0.111 & 0.217 & 0.242 & 0.194 & 0.219 & 0.221 & 0.261 \\
\hline Number of cntid & 89 & 89 & 89 & 89 & 89 & 86 & 86 & 86 & 85 \\
\hline Hausman test ( $p$-value) & 0.886 & 0.0955 & 0.484 & 0.397 & 0.0779 & 0.0480 & 0.000151 & 0.000287 & $7.27 \mathrm{e}-05$ \\
\hline F-test on finreform_cor ( $p$-value) & & & & & 0.00115 & & 0.000105 & $6.11 \mathrm{e}-05$ & 0.00153 \\
\hline F-test on democ (p-value) & & & & & & & 0.00378 & 0.00457 & 0.00218 \\
\hline F-test on domcredgdp ( $p$-value) & & & & & $5.11 \mathrm{e}-06$ & & & 0.0116 & \\
\hline
\end{tabular}

Table 3. Finance and income inequality: panel estimates (dependent variable: Gini coefficient; economic freedom data for financial liberalization)

\begin{tabular}{|c|c|c|c|c|c|c|c|c|c|}
\hline VARIABLES & (1) & (2) & (3) & (4) & $\begin{array}{c}\text { (5) } \\
\text { +interaction } \\
\end{array}$ & $\begin{array}{c}(6) \\
+ \text { democ } \\
\end{array}$ & $\begin{array}{c}(7) \\
+ \text { democ } \\
\end{array}$ & $\begin{array}{c}(8) \\
+ \text { democ } \\
\end{array}$ & $\begin{array}{c}\text { (9) } \\
\text { +ec.glob-flows } \\
\end{array}$ \\
\hline Start of a Systemic Banking Crisis during $\mathrm{t}-7$ and $\mathrm{t}-3$ & $\begin{array}{c}1.225^{* * * *} \\
(2.776)\end{array}$ & & & $\begin{array}{c}1.453^{* * * *} \\
(3.210)\end{array}$ & $\begin{array}{c}1.394^{* * * *} \\
(3.261)\end{array}$ & $\begin{array}{c}1.047^{* * * *} \\
(2.718)\end{array}$ & $\begin{array}{l}0.951^{* *} \\
(2.548)\end{array}$ & $\begin{array}{l}0.910^{* * *} \\
(2.579)\end{array}$ & $\begin{array}{l}0.923^{* *} \\
(2.504)\end{array}$ \\
\hline Domestic credit to private sector (\% of GDP) & & $\begin{array}{c}0.0603^{* * *} \\
(4.654)\end{array}$ & & $\begin{array}{c}0.0538^{* * *} \\
(4.462)\end{array}$ & $\begin{array}{l}-0.0305 \\
(-0.736)\end{array}$ & $\begin{array}{c}0.0367^{* * *} \\
(3.886)\end{array}$ & $\begin{array}{c}0.0305^{* * *} \\
(3.457)\end{array}$ & $\begin{array}{l}0.0572 \\
(1.330)\end{array}$ & $\begin{array}{c}0.0217^{* *} \\
(2.557)\end{array}$ \\
\hline Financial lib.: Avg. of EFW-areas 3D, $4 \mathrm{C}, 4 \mathrm{D}$ and $5 \mathrm{~A}$ & & & $\begin{array}{l}0.426^{* *} \\
(2.451)\end{array}$ & $\begin{array}{c}0.244 \\
(1.650)\end{array}$ & $\begin{array}{l}-0.0502 \\
(-0.215)\end{array}$ & $\begin{array}{c}0.190 \\
(1.497)\end{array}$ & $\begin{array}{l}-0.639^{*} \\
(-1.908)\end{array}$ & $\begin{array}{c}-0.736^{* *} \\
(-2.259)\end{array}$ & $\begin{array}{l}-0.589^{*} \\
(-1.906)\end{array}$ \\
\hline c.domcredgdp\#c.ffw_avg & & & & & $\begin{array}{c}0.00942^{* *} \\
(2.113)\end{array}$ & & & & \\
\hline ICRG: Democratic Accountability & & & & & & $\begin{array}{c}-0.727^{* * * *} \\
(-2.785)\end{array}$ & $\begin{array}{c}-2.146^{* * *} \\
(-3.487)\end{array}$ & $\begin{array}{c}-2.061^{* * *} \\
(-3.261)\end{array}$ & $\begin{array}{c}-1.941^{* * *} \\
(-3.396)\end{array}$ \\
\hline c.democttc.ffw_avg & & & & & & & $\begin{array}{c}0.224^{* * * *} \\
(2.928)\end{array}$ & $\begin{array}{c}0.245^{* * *} \\
(3.128)\end{array}$ & $\begin{array}{l}0.182^{* * *} \\
(2.542)\end{array}$ \\
\hline c.domcredgdp\#c.democ & & & & & & & & $\begin{array}{r}-0.00506 \\
(-0.690)\end{array}$ & \\
\hline Economic Globalization: Actual Flows & & & & & & & & & $\begin{array}{c}0.0840^{* * * *} \\
(3.572)\end{array}$ \\
\hline Observations & 518 & 518 & 518 & 518 & 518 & 410 & 410 & 410 & 403 \\
\hline R-squared & 0.017 & 0.126 & 0.044 & 0.157 & 0.177 & 0.123 & 0.162 & 0.166 & 0.215 \\
\hline Number of cntid & 121 & 121 & 121 & 121 & 121 & 110 & 110 & 110 & 109 \\
\hline Hausman test (p-value) & 0.818 & 0.00972 & 0.388 & 0.0704 & 0.0319 & 0.173 & 0.0781 & 0.0659 & 0.0568 \\
\hline F-test on ffw_avg (p-value) & & & & & 0.00561 & & 0.00135 & 0.00139 & 0.0217 \\
\hline F-test on democ (p-value) & & & & & & & 0.00259 & 0.00739 & 0.00203 \\
\hline F-test on domcredgdp (p-value) & & & & & $8.43 e-06$ & & & 0.00216 & \\
\hline
\end{tabular}


Table 4. Random effects GLS and G2SLS estimates

\begin{tabular}{|c|c|c|c|c|c|c|c|c|}
\hline & \multicolumn{4}{|c|}{ Abiad et al. index (corrected) } & \multicolumn{4}{|c|}{ Avg.of EFW-areas 3D, 4C, 4D and 5A } \\
\hline & (1) & $(2)$ & (3) & (4) & (5) & (6) & (7) & (8) \\
\hline VARIABLES & $\mathrm{FD}$ & $+\mathrm{IV}$ & $\mathrm{PI}$ & $+\mathrm{IV}$ & FD & $+\mathrm{IV}$ & $\mathrm{PI}$ & $+\mathrm{IV}$ \\
\hline Start of a Systemic Banking Crisis during t-7 and t-3 & $\begin{array}{l}1.012^{* *} \\
(2.513)\end{array}$ & $\begin{array}{c}0.954 * * * \\
(2.687)\end{array}$ & $\begin{array}{c}1.017 * * * \\
(2.862)\end{array}$ & $\begin{array}{c}1.023 * * * \\
(3.559)\end{array}$ & $\begin{array}{c}1.436 * * * \\
(3.441)\end{array}$ & $\begin{array}{c}1.221^{* * *} \\
(2.979)\end{array}$ & $\begin{array}{c}1.010^{* * *} \\
(2.720)\end{array}$ & $\begin{array}{c}1.000 * * * \\
(3.098)\end{array}$ \\
\hline Domestic credit to private sector (\% of GDP) & $\begin{array}{l}-0.0188 \\
(-0.578)\end{array}$ & $\begin{array}{c}-0.0872 * \\
(-1.790)\end{array}$ & $\begin{array}{c}0.0283^{* * *} \\
(3.426)\end{array}$ & $\begin{array}{l}0.0124 \\
(0.560)\end{array}$ & $\begin{array}{l}-0.0358 \\
(-0.900)\end{array}$ & $\begin{array}{c}-0.138^{* *} \\
(-2.362)\end{array}$ & $\begin{array}{c}3.0277^{* * *} \\
(3.613)\end{array}$ & $\begin{array}{c}0.00508 \\
(0.191)\end{array}$ \\
\hline Financial liberalisation & $\begin{array}{l}0.0338 \\
(0.455)\end{array}$ & $\begin{array}{c}-0.00983 \\
(-0.137)\end{array}$ & $\begin{array}{c}-0.109 \\
(-0.924)\end{array}$ & $\begin{array}{c}-0.179 \\
(-1.565)\end{array}$ & $\begin{array}{l}-0.0401 \\
(-0.180)\end{array}$ & $\begin{array}{l}-0.0317 \\
(-0.128)\end{array}$ & $\begin{array}{l}-0.618^{*} \\
(-1.860)\end{array}$ & $\begin{array}{c}-0.712^{* *} \\
(-2.374)\end{array}$ \\
\hline c.domcredgdp\#c.finlib & $\begin{array}{c}0.00391^{* *} \\
(2.202)\end{array}$ & $\begin{array}{c}0.00708^{* * *} \\
(3.688)\end{array}$ & & & $\begin{array}{c}0.00919 * * \\
(2.087)\end{array}$ & $\begin{array}{c}0.0167^{* * *} \\
(2.696)\end{array}$ & & \\
\hline ICRG: Democratic Accountability & & & $\begin{array}{c}-1.456 * * * \\
(-3.092)\end{array}$ & $\begin{array}{c}-1.706 * * * \\
(-3.569)\end{array}$ & & & $\begin{array}{c}-2.020 * * * \\
(-3.257)\end{array}$ & $\begin{array}{c}*-2.236 * * * \\
(-4.265)\end{array}$ \\
\hline c.democ\#c.finlib & & & $\begin{array}{c}0.0817 * * * \\
(2.722)\end{array}$ & $\begin{array}{c}0.105^{* * *} \\
(3.640)\end{array}$ & & & $\begin{array}{c}0.217^{* * *} \\
(2.831)\end{array}$ & $\begin{array}{c}0.258^{* * *} \\
(3.987)\end{array}$ \\
\hline Observations & 426 & 426 & 345 & 345 & 518 & 518 & 410 & 410 \\
\hline Number of cntid & 89 & 89 & 86 & 86 & 121 & 121 & 110 & 110 \\
\hline F-test on domcredgdp ( $p$-value) & 8.57e-08 & & & & $3.80 \mathrm{e}-06$ & & & \\
\hline F-test on finlib ( $p$-value) & 0.000673 & 0.000638 & $4.49 e-05$ & $1.77 e-05$ & 0.00761 & 0.00141 & 0.00187 & 0.000113 \\
\hline F-test on democ ( $p$-value) & & & 0.00836 & 0.000754 & & & 0.00436 & $9.09 e-05$ \\
\hline
\end{tabular}

Table 5. Cross-country regressions

\begin{tabular}{|c|c|c|c|c|c|c|c|c|c|}
\hline \multirow[b]{3}{*}{ VARIABLES } & \multirow{3}{*}{$\begin{array}{c}\text { (1) } \\
1991-1995\end{array}$} & \multirow[b]{2}{*}{ (2) } & \multirow[b]{2}{*}{ (3) } & \multirow[b]{2}{*}{ (4) } & \multirow[b]{2}{*}{ (5) } & \multirow[b]{2}{*}{ (6) } & \multicolumn{3}{|c|}{ Instrumental variables } \\
\hline & & & & & & & (7) & (8) & (9) \\
\hline & & $1991-2000$ & 1991-2005 & $1996-2000$ & $1996-2005$ & $1996-2010$ & $1996-2000$ & $1996-2005$ & $1996-2010$ \\
\hline \multirow[t]{2}{*}{ Start of a Systemic Banking Crisis during $t-7$ and $t-3$} & 0.782 & 0.720 & 0.515 & $4.104^{* *}$ & $3.686^{* *}$ & $3.454^{* *}$ & $3.224^{*}$ & 2.992 & 2.804 \\
\hline & $(-0.417)$ & $(-0.379)$ & $(-0.279)$ & $(2.444)$ & (2.322) & (2.152) & $(1.702)$ & (1.412) & (1.583) \\
\hline \multirow[t]{2}{*}{ Domestic credit to private sector (\% of GDP) } & $0.0455^{*}$ & $-0.0438^{\prime \prime}$ & 0.0309 & 0.00606 & 0.00561 & 0.00755 & -0.0690 & -0.0452 & -0.0325 \\
\hline & $(-1.779)$ & $(-1.688)$ & $(-1.227)$ & $(-0.269)$ & $(0.265)$ & $(0.372)$ & $(-1.277)$ & $(-0.910)$ & $(-0.813)$ \\
\hline \multirow[t]{2}{*}{ Financial lib.: Abiad et al. index (corrected) } & 0.762 & $1.029^{* *}$ & $1.097^{* * *}$ & $1.372^{* *}$ & $1.188^{* *}$ & 1.007 & $1.312^{* *}$ & $1.223^{* *}$ & 1.143 \\
\hline & (1.569) & $(2.088)$ & (2.293) & $(2.183)$ & $(2.009)$ & (1.664) & $(2.196)$ & (2.059) & $(1.600)$ \\
\hline \multirow[t]{2}{*}{ ICRG: Democratic Accountability } & 1.620 & 2.195 & $2.458^{*}$ & 0.381 & 0.218 & 0.0577 & -0.430 & -0.305 & -0.0928 \\
\hline & (1.160) & (1.550) & (1.783) & $(0.179)$ & (0.109) & $(0.0279)$ & $(-0.186)$ & $(-0.138)$ & $(-0.0338)$ \\
\hline \multirow[t]{2}{*}{ c.democHc.finreform_cor } & -0.118 & -0.180 & $-0.207^{*}$ & -0.126 & -0.110 & -0.0817 & -0.0327 & -0.0482 & -0.0526 \\
\hline & $(-1.050)$ & $(-1.577)$ & $(-1.871)$ & $(-0.819)$ & $(-0.756)$ & $(-0.558)$ & $(-0.182)$ & $(-0.273)$ & $(-0.263)$ \\
\hline Observations & 66 & 66 & 65 & 78 & 77 & 66 & 78 & 77 & 66 \\
\hline R-squared & 0.084 & 0.101 & 0.099 & 0.198 & 0.183 & 0.187 & 0.235 & 0.222 & 0.221 \\
\hline F-test on finreform_cor ( $p$-value) & 0.191 & 0.0876 & 0.0691 & 0.00222 & 0.00540 & 0.0125 & $5.57 \mathrm{e}-05$ & $1.59 \mathrm{e}-06$ & 0.000126 \\
\hline F-test on democ ( $p$-value) & 0.514 & 0.281 & 0.177 & 0.184 & 0.182 & 0.289 & 0.593 & 0.496 & 0.584 \\
\hline
\end{tabular}


Table 6. Regressions including only OECD countries

\begin{tabular}{|c|c|c|c|c|c|c|}
\hline & \multicolumn{3}{|c|}{ Abiad et al. index (corrected) } & \multicolumn{3}{|c|}{ Avg.of EFW-areas 3D, 4C, 4D and 5A } \\
\hline & (1) & (2) & (3) & (4) & (5) & (6) \\
\hline VARIABLES & no interaction & interaction & +democ & no interaction & interaction & + democ \\
\hline Start of a Systemic Banking Crisis during t -7 and $t-3$ & $\begin{array}{c}2.872^{* * *} \\
(5.154)\end{array}$ & $\begin{array}{c}2.763^{* * *} \\
(5.225)\end{array}$ & $\begin{array}{c}2.140 * * * \\
(3.907)\end{array}$ & $\begin{array}{c}2.784 * * * \\
(3.941)\end{array}$ & $\begin{array}{c}2.703^{* * *} \\
(3.916)\end{array}$ & $\begin{array}{c}1.915^{* * *} \\
(2.848)\end{array}$ \\
\hline Domestic credit to private sector (\% of GDP) & $\begin{array}{c}0.0636^{* * *} \\
(4.347)\end{array}$ & $\begin{array}{l}0.0395 \\
(0.783)\end{array}$ & $\begin{array}{c}0.0412^{* *} \\
(2.537)\end{array}$ & $\begin{array}{c}0.0571^{* * *} \\
(3.989)\end{array}$ & $\begin{array}{l}0.0369 \\
(0.435)\end{array}$ & $\begin{array}{c}0.0385^{* * *} \\
(3.294)\end{array}$ \\
\hline Financial liberalisation & $\begin{array}{c}0.302 * * \\
(2.732)\end{array}$ & $\begin{array}{c}0.229 \\
(1.246)\end{array}$ & $\begin{array}{l}-0.0980 \\
(-0.112)\end{array}$ & $\begin{array}{c}0.768^{* *} \\
(2.596)\end{array}$ & $\begin{array}{c}0.645 \\
(1.129)\end{array}$ & $\begin{array}{c}-0.743 \\
(-0.422)\end{array}$ \\
\hline c.domcredgdp\#c.finlib & & $\begin{array}{c}0.00142 \\
(0.513)\end{array}$ & & & $\begin{array}{c}0.00227 \\
(0.242)\end{array}$ & \\
\hline ICRG: Democratic Accountability & & & $\begin{array}{c}-1.750 \\
(-0.731)\end{array}$ & & & $\begin{array}{c}-2.133 \\
(-0.961)\end{array}$ \\
\hline c.democ\#c.finlib & & & $\begin{array}{l}0.0913 \\
(0.546)\end{array}$ & & & $\begin{array}{c}0.239 \\
(0.766)\end{array}$ \\
\hline Observations & 136 & 136 & 99 & 144 & 144 & 106 \\
\hline R-squared & 0.567 & 0.569 & 0.376 & 0.498 & 0.499 & 0.290 \\
\hline Number of cntid & 22 & 22 & 22 & 24 & 24 & 24 \\
\hline Hausman test ( $p$-value) & $4.79 \mathrm{e}-06$ & $1.79 \mathrm{e}-05$ & 0.000898 & 0 & 0 & 0.000209 \\
\hline F-test on domcredgdp ( $p$-value) & & 0.00122 & & & 0.00250 & \\
\hline F-test on finlib (p-value) & & 0.0381 & 0.181 & & 0.0555 & 0.174 \\
\hline F-test on democ ( $p$-value) & & & 0.673 & & & 0.591 \\
\hline
\end{tabular}




\section{Figures}

Figure 1. Financial development (credit/GDP) and income inequality (Gini coefficients)
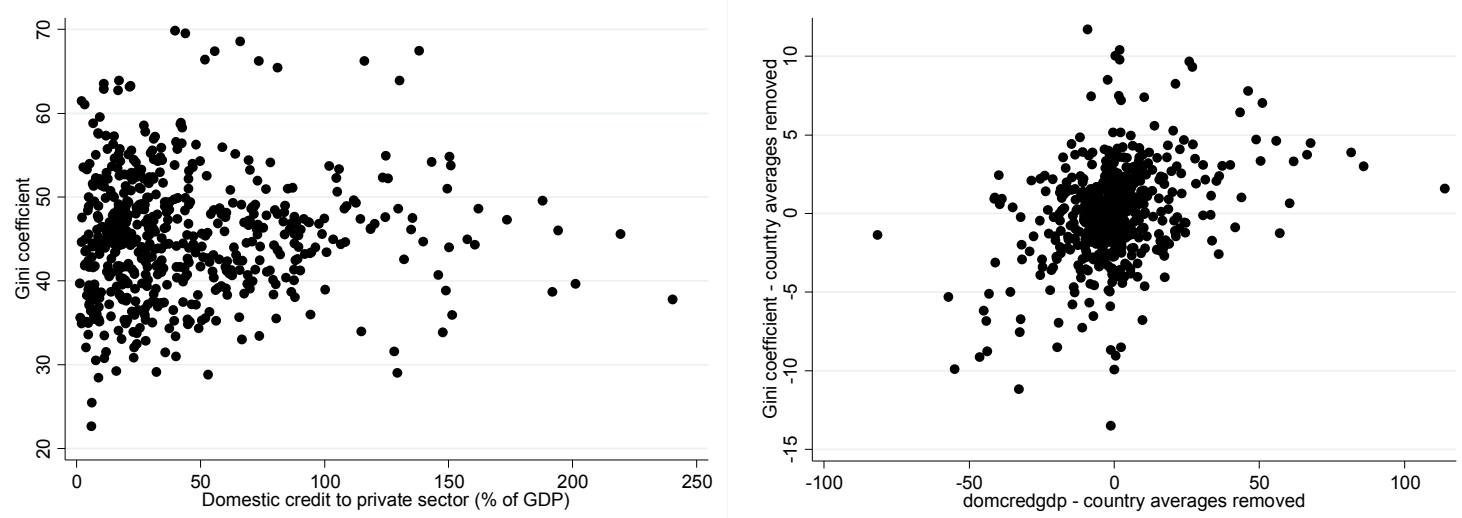

Figure 2. Financial liberalization (Abiad et al. measure) and income inequality (Gini coefficients)
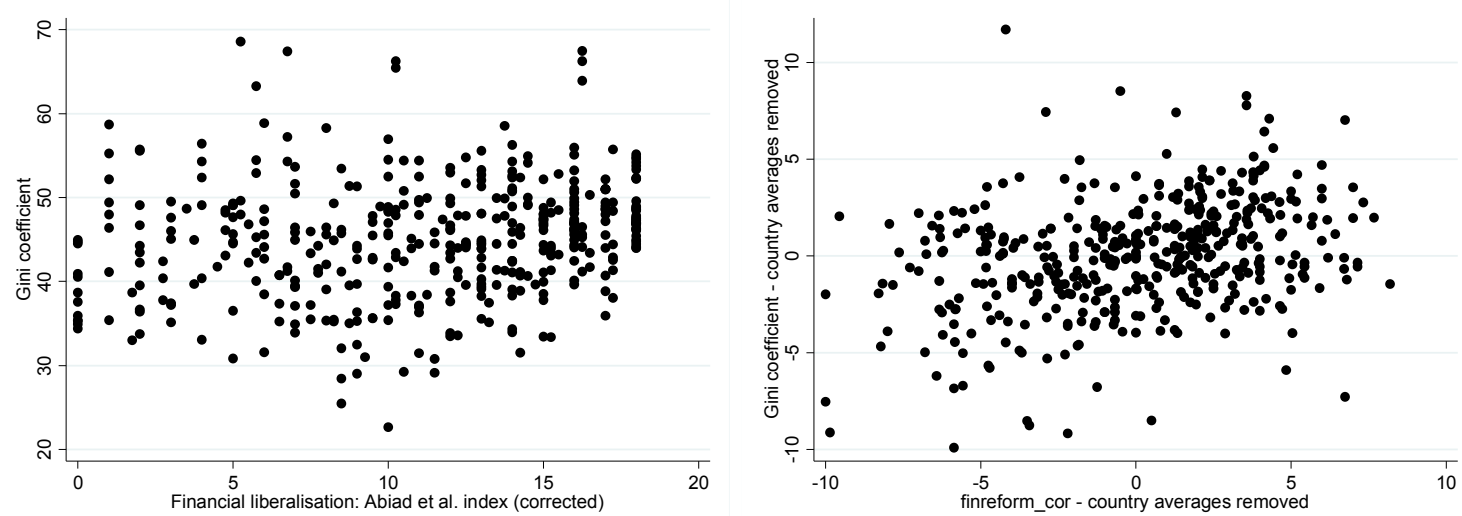
Figure 3. Financial liberalization (economic freedom measure) and income inequality (Gini coefficients)
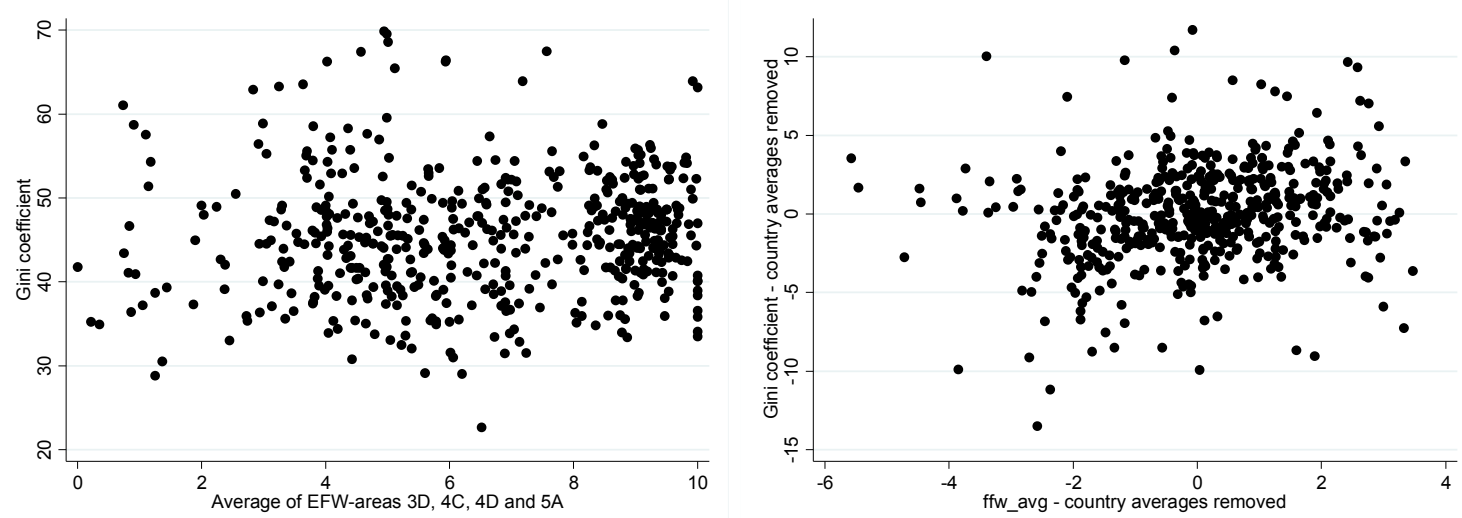

Figure 4. Marginal impact of financial liberalization on income inequality for different levels of financial development
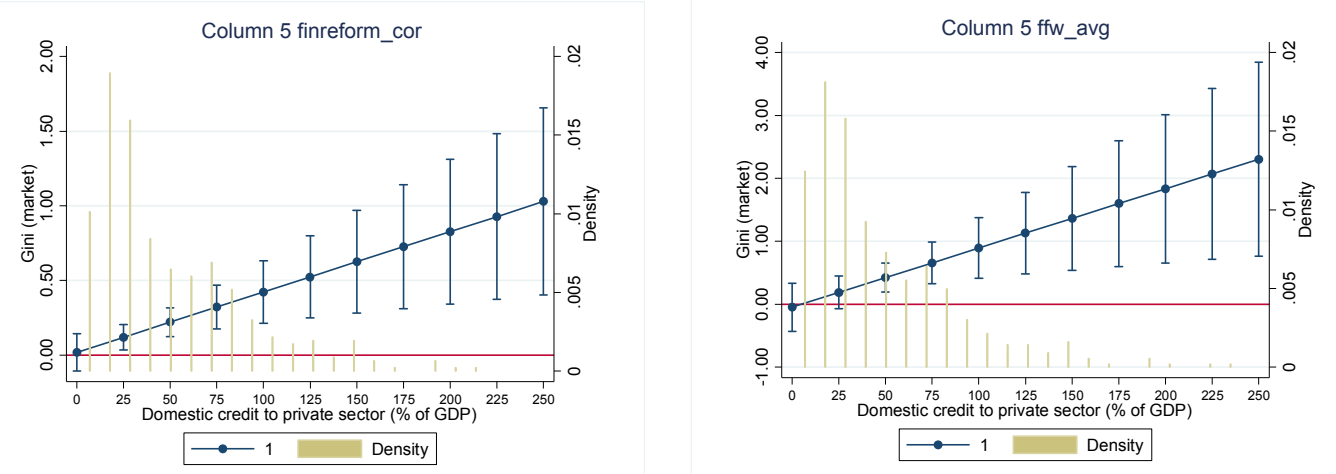

Figure 5. Marginal impact of financial liberalization on income inequality for different levels of democratic accountability
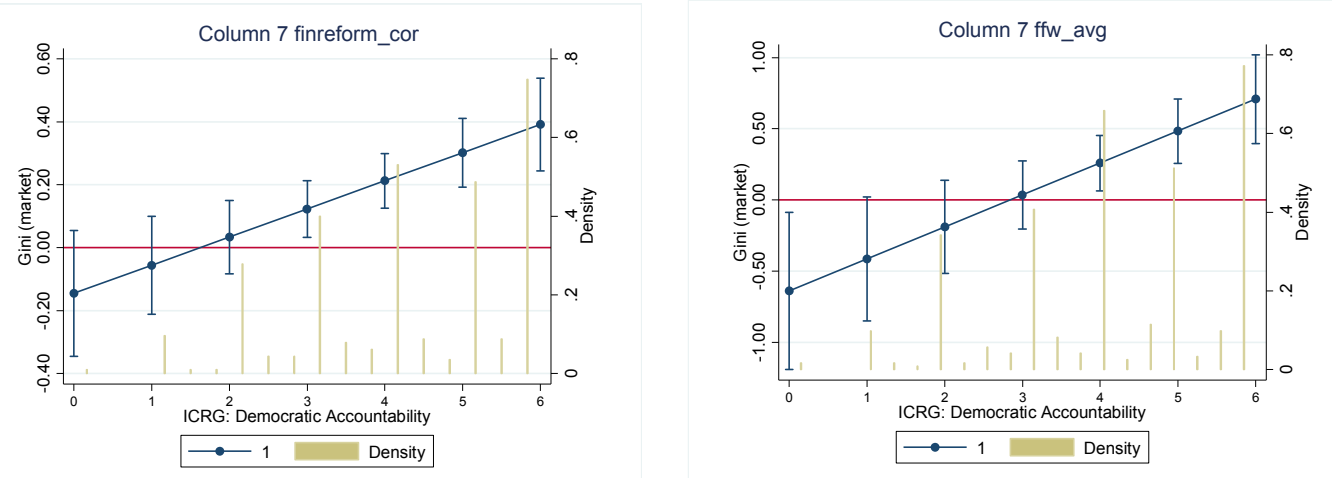
Figure 6. Marginal impact of financial development on income inequality for different levels of democratic accountability
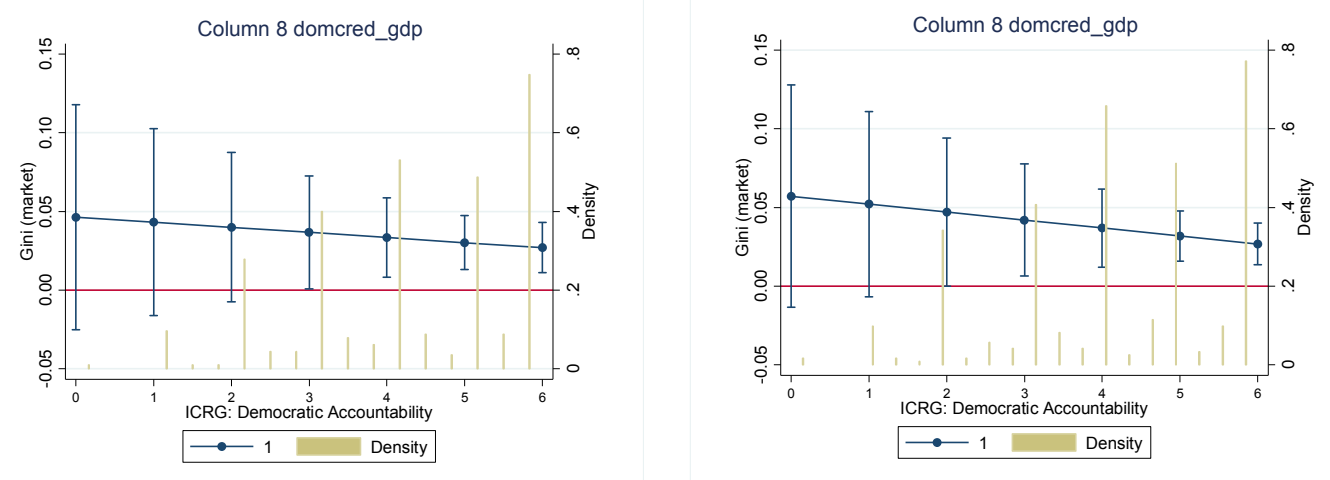


\section{Appendix}

Table A1. Countries included

\begin{tabular}{|c|c|c|c|c|c|c|c|c|c|c|c|}
\hline Country $\mid O b s$. & $\begin{array}{l}\dot{\pi} \\
+\frac{0}{0} \\
\frac{\pi}{0} \\
\frac{\pi}{0} \\
\frac{1}{\alpha}\end{array}$ & 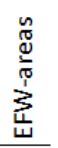 & Country $\backslash$ Obs. & $\begin{array}{l}\dot{\pi} \\
+\frac{0}{0} \\
\frac{0}{0} \\
\frac{\pi}{0} \\
\frac{0}{4}\end{array}$ & 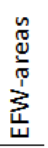 & Country $\backslash$ Obs. & $\begin{array}{l}\dot{\pi} \\
\stackrel{0}{0} \\
\frac{0}{0} \\
\frac{\pi}{0} \\
\dot{\leftarrow}\end{array}$ & 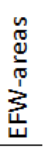 & Country $\mid$ Obs. & 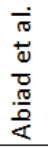 & $\begin{array}{l}\stackrel{n}{\pi} \\
\frac{d}{d} \\
\frac{\pi}{1} \\
\frac{3}{W} \\
\end{array}$ \\
\hline Albania & 2 & $\overline{2}$ & El Salvador & 4 & $\overline{4}$ & Lesotho & 0 & 2 & Russia & 3 & 3 \\
\hline Algeria & 3 & 3 & Estonia & 3 & 3 & Lithuania & 1 & 1 & Rwanda & 0 & 5 \\
\hline Argentina & 6 & 6 & Ethiopia & 4 & 1 & Luxembourg & 0 & 5 & Senegal & 4 & 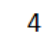 \\
\hline Armenia & 0 & 1 & Fiji & 0 & 3 & Macedonia & 0 & 2 & Sierra Leone & 0 & 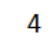 \\
\hline Australia & 7 & 7 & Finland & 6 & 6 & Madagascar & 3 & 3 & Singapore & 7 & 7 \\
\hline Austria & 4 & 4 & France & 6 & 6 & Malawi & 0 & 5 & Slovak Republic & 0 & - \\
\hline Azerbaijan & 2 & 2 & Georgia & 3 & 2 & Malaysia & 5 & 5 & Slovenia & 0 & 3 \\
\hline Bangladesh & 7 & 7 & Germany & 6 & 6 & Mali & 0 & 4 & South Africa & 7 & 7 \\
\hline Barbados & 0 & 3 & Ghana & 3 & 3 & Mauritius & 0 & 4 & South Korea & 7 & 7 \\
\hline Belarus & 3 & 0 & Greece & 7 & 7 & Mexico & 7 & 7 & Spain & 5 & 5 \\
\hline Belgium & 6 & 6 & Guatemala & 4 & 4 & Moldova & 0 & 2 & Sri Lanka & 6 & 6 \\
\hline Bolivia & 5 & 5 & Guinea-Bissau & 0 & 3 & Mongolia & 0 & 3 & Sweden & 7 & 7 \\
\hline Botswana & 0 & 4 & Guyana & 0 & 2 & Morocco & 5 & 5 & Switzerland & 4 & 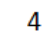 \\
\hline Brazil & 6 & 6 & Haiti & 0 & 1 & Mozambique & 2 & 1 & Syria & 0 & 1 \\
\hline Bulgaria & 3 & 3 & Honduras & 0 & 4 & Namibia & 0 & 3 & Tanzania & 4 & 4 \\
\hline Burkina Faso & 2 & 0 & Hong Kong & 4 & 4 & Nepal & 3 & 3 & Thailand & 5 & 5 \\
\hline Burundi & 0 & 2 & Hungary & 3 & 3 & Netherlands & 6 & 6 & Togo & 0 & 1 \\
\hline Cameroon & 2 & 2 & Iceland & 0 & 3 & New Zealand & 7 & 7 & Trinidad and Tobago & 0 & 3 \\
\hline Canada & 7 & 7 & India & 7 & 7 & Nicaragua & 2 & 2 & Tunisia & 5 & 5 \\
\hline Central African Republic & 0 & 2 & Indonesia & 6 & 6 & Niger & 0 & 2 & Turkey & 5 & 5 \\
\hline Chile & 6 & 6 & Iran & 0 & 6 & Nigeria & 5 & 5 & Uganda & 4 & 4 \\
\hline China & 5 & 6 & Ireland & 6 & 6 & Norway & 7 & 7 & Ukraine & 3 & 3 \\
\hline Colombia & 7 & 7 & Israel & 6 & 6 & Pakistan & 7 & 7 & United Kingdom & 7 & 7 \\
\hline Costa Rica & 5 & 5 & Italy & 6 & 6 & Panama & 0 & 7 & United States & 7 & 7 \\
\hline Cote d'Ivoire & 4 & 4 & Jamaica & 3 & 3 & Papua New Guinea & 0 & 2 & Uruguay & 7 & 7 \\
\hline Croatia & 0 & 3 & Japan & 7 & 7 & Paraguay & 4 & 4 & Venezuela & 7 & 7 \\
\hline Czech Republic & 3 & 3 & Jordan & 5 & 5 & Peru & 5 & 5 & Vietnam & 3 & 2 \\
\hline Denmark & 7 & 7 & Kazakhstan & 3 & 2 & Philippines & 5 & 5 & Yugoslavia & 0 & 1 \\
\hline Dominican Republic & 5 & 5 & Kenya & 5 & 5 & Poland & 4 & 4 & Zambia & 0 & 4 \\
\hline Ecuador & 5 & 5 & Kyrgyz Republic & 3 & 3 & Portugal & 6 & 6 & Zimbabwe & 3 & 3 \\
\hline Egypt & 5 & 5 & Latvia & 3 & 3 & Romania & 2 & 2 & & & \\
\hline
\end{tabular}

Total countries $\quad 89121$

Total observations $\quad 426518$ 
Table A2. Variables: Description and sources

\begin{tabular}{|c|c|c|}
\hline Variable & Description & Source \\
\hline \multicolumn{3}{|l|}{ Main variables } \\
\hline gini & Gini coefficient using (pre-tax, pre-transfer) household income & SWIID \\
\hline dumsysbankcr & Start of a Systemic Banking Crisis & Laeven and Valencia \\
\hline domcredgdp & Domestic credit to private sector (\% of GDP) & WDI \\
\hline finreform_corr & Financial liberalisation: Abiad et al. index (corrected) & Abiad et al. \\
\hline ffw_avg & Average of EFW-areas $3 \mathrm{D}, 4 \mathrm{C}, 4 \mathrm{D}$ and $5 \mathrm{~A}$ & EFW \\
\hline \multicolumn{3}{|l|}{ Additional variables } \\
\hline govconsgdp & General government final consumption expenditure (\% of GDP) & WDI \\
\hline Irgdppc & Log(GDP per capita - constant 2005 US\$̧) & WDI \\
\hline tradegdp & Trade (\% of GDP) & WDI \\
\hline Ipop & Log(Population) & WDI \\
\hline inflation & Inflation, consumer prices (annual \%) & WDI \\
\hline grrgdp & GDP growth (annual \%) & WDI \\
\hline agrshare & Agriculture, value added (\% of GDP) & WDI \\
\hline indshare & Industry, value added (\% of GDP) & WDI \\
\hline natresshare & Total natural resources rents (\% of GDP) & WDI \\
\hline efw_avg & Average of non-financial EFW-areas & EFW \\
\hline kaopen & Chinn-Ito index & Chinn and Ito \\
\hline left & Orientation of the Chief Executive Party is left-wing & DPI \\
\hline civlib & Freedom in the World: Civil Liberties & Freedom House \\
\hline eduexpgni & Adjusted savings: education expenditure (\% of GNI) & WDI \\
\hline schoolenrprim & School enrollment, primary (\% gross) & WDI \\
\hline schoolenrsec & School enrollment, secondary (\% gross) & WDI \\
\hline schoolenrtert & School enrollment, tertiary (\% gross) & WDI \\
\hline glob_act_flows & Economic Globalization: Actual Flows & KOF \\
\hline glob_restr & Economic Globalization: Restrictions & KOF \\
\hline glob_soc & Social Globalization & KOF \\
\hline glob_pol & Political Globalization & KOF \\
\hline polrel & Ethnic Polarization (relevant groups), EPR & EPR-ETH \\
\hline elfrel & Ethnic Fractionalization (relevant groups), EPR & EPR-ETH \\
\hline lifeexpect & Life expectancy at birth, total (years) & WDI \\
\hline termsoftrade & Net barter terms of trade index $(2000=100)$ & WDI \\
\hline fdigdp & Foreign direct investment, net inflows ( $\%$ of GDP) & WDI \\
\hline gfcfgdp & Gross fixed capital formation (\% of GDP) & WDI \\
\hline instqual & Institutional Quality (corru burea law_a democ) & ICRG \\
\hline democ & Democratic Accountability & ICRG \\
\hline dumcurcr & Start of a Currency Crisis & Laeven and Valencia \\
\hline dumsovdebtcr & Sovereign Debt Crisis (default date) & Laeven and Valencia \\
\hline dumsovdebtrestruct & Sovereign Debt Restructuring year & Laeven and Valencia \\
\hline
\end{tabular}


Table A3. Summary statistics

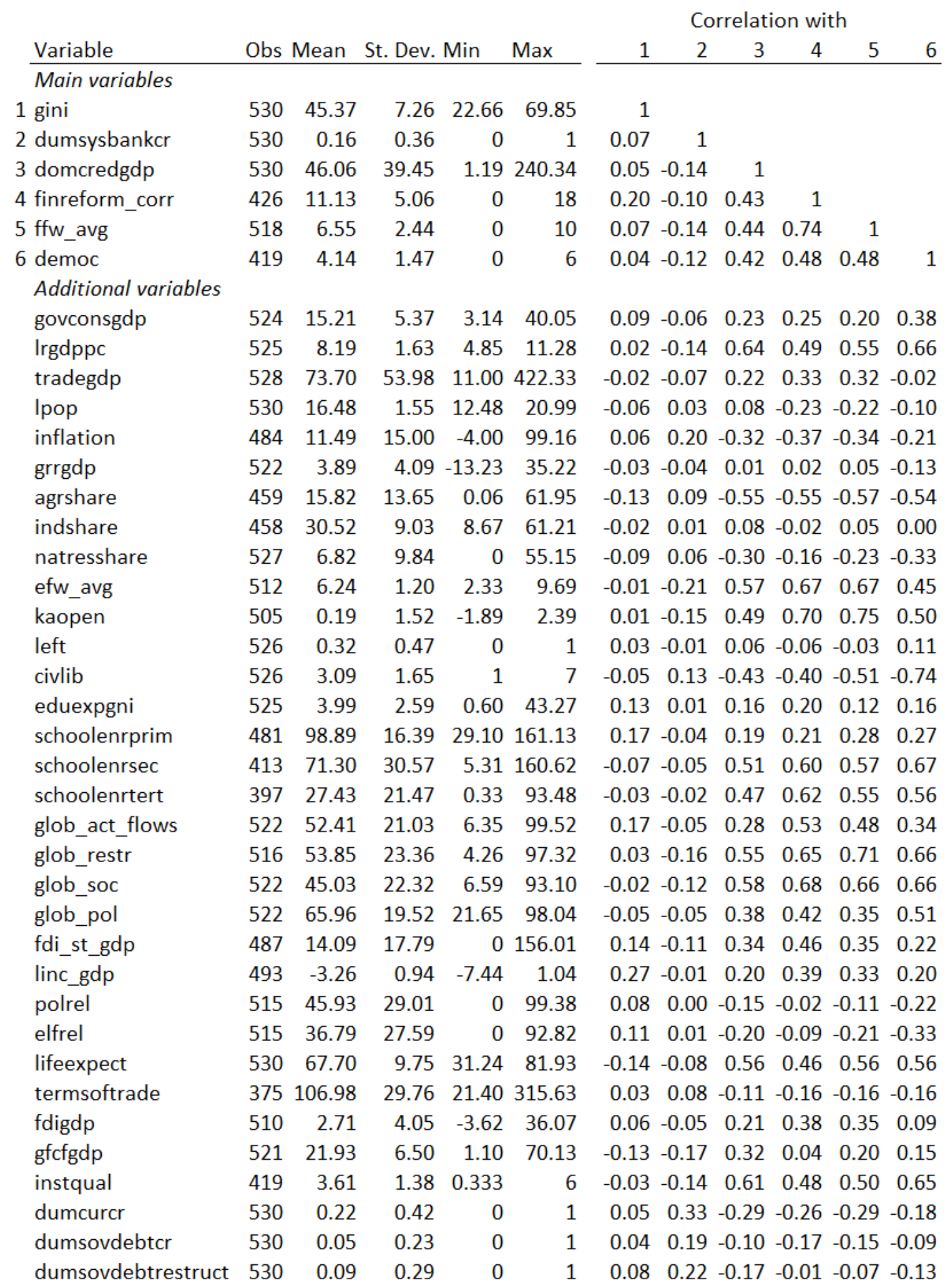


Table A4. Correlation matrix

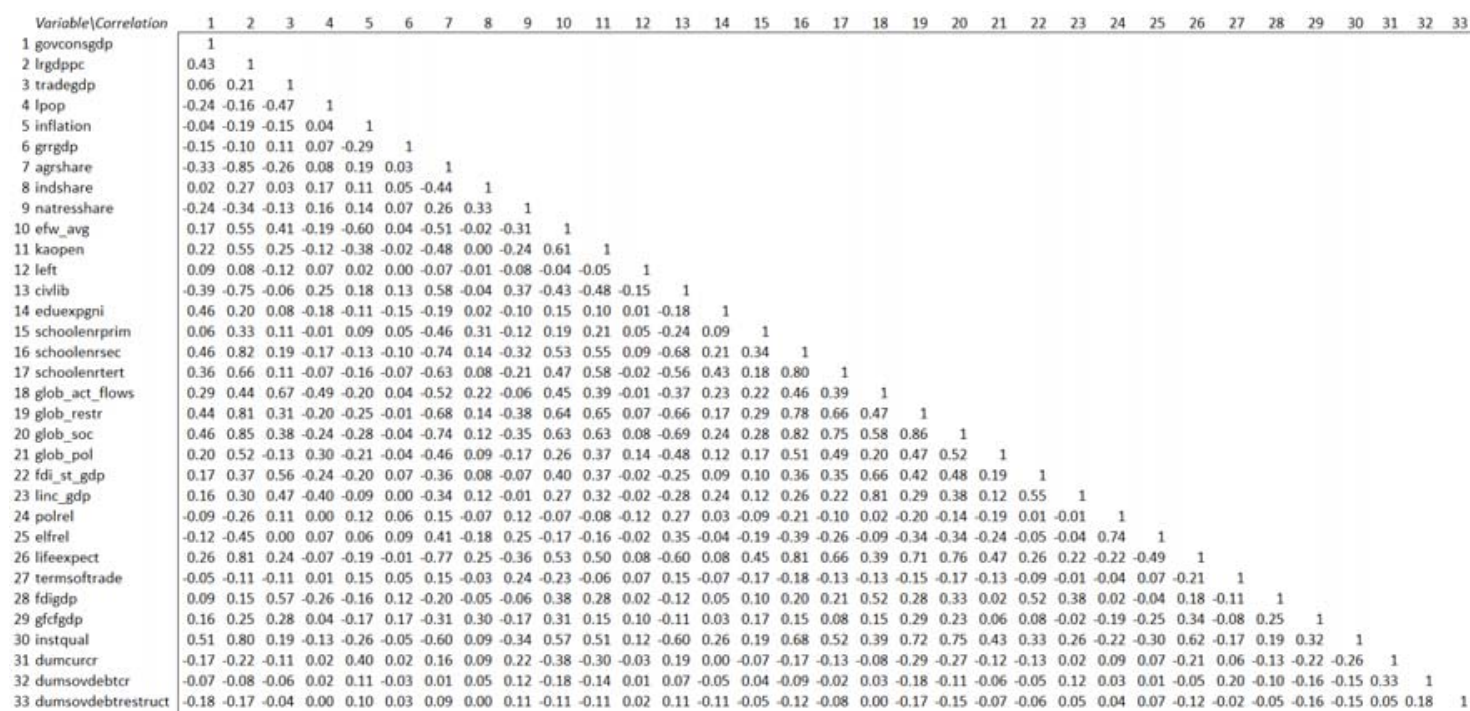

Figure A1. Marginal effects of financial development on the Gini coefficient for different values of the quality of economic institutions

Table 2 - finreform_cor

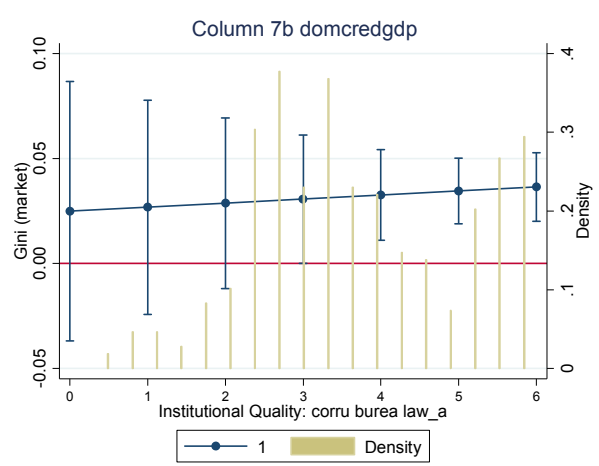

Table 3 - ffw_avg

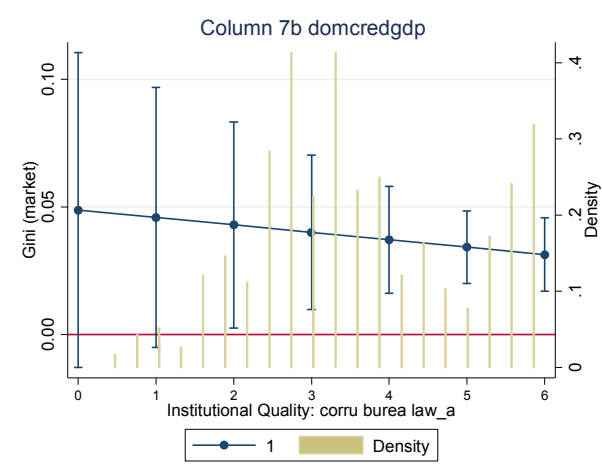


Figure A2. Marginal effects of financial liberalization on the Gini coefficient for different values of financial development and political institutional quality estimated with G2SLS
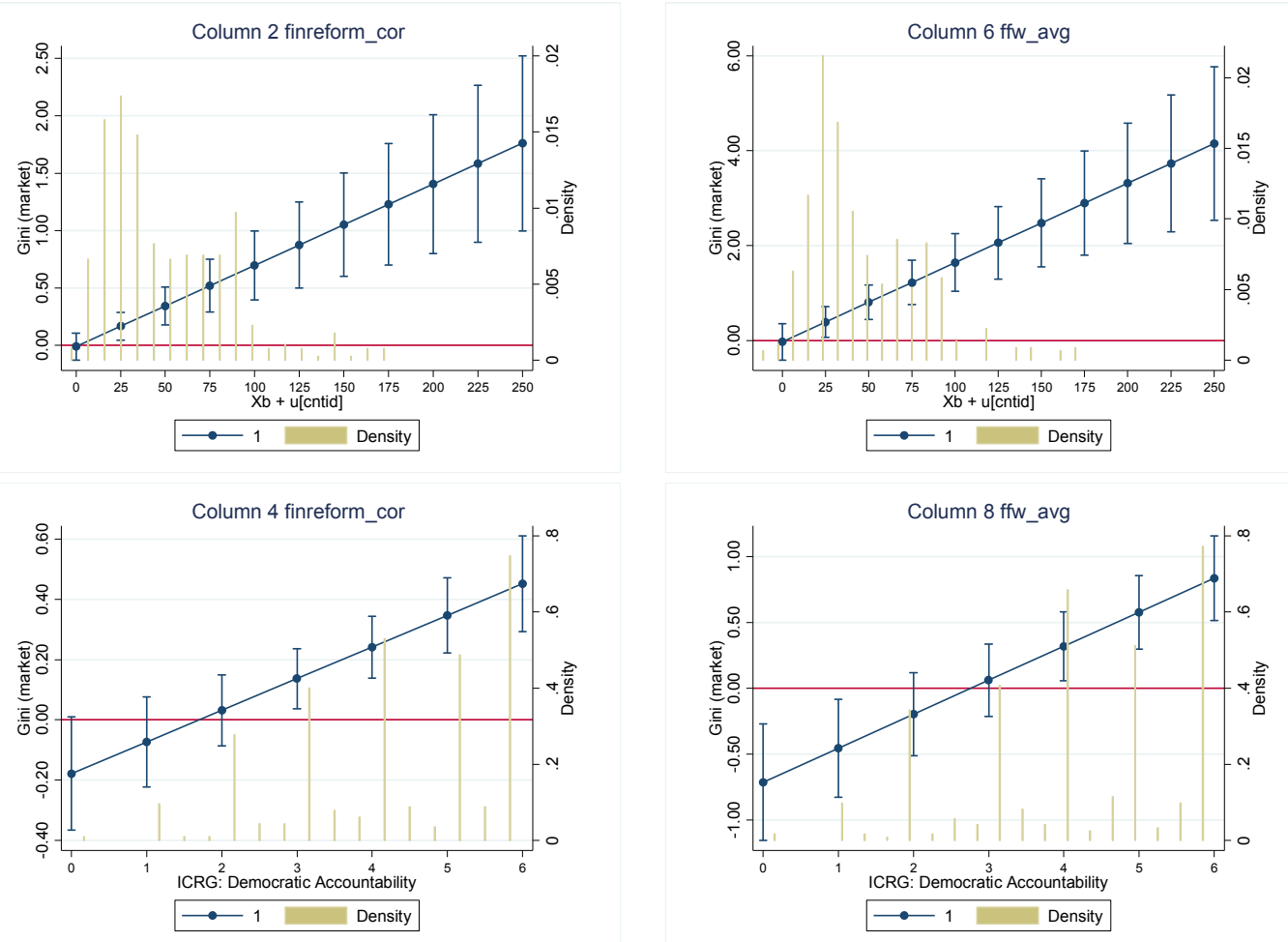